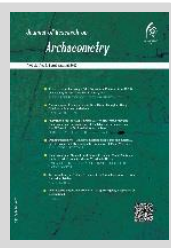

Original Paper

\title{
Geo-Archaeology of West Susiana Plain with an Analysis of Hydraulic Structures
}

\author{
Amir Safari ${ }^{1}$, Amir Karam $^{2}$, Alireza Sardari Zarchi ${ }^{3}$, Morteza Fattahi $^{4}$, Reza Motamed $^{5 \times}$ \\ ${ }^{1}$ Associate Professor of Geography, Kharazmi University of Tehran, Tehran, IRAN \\ ${ }^{2}$ Associate Professor of Natural Geography, Kharazmi University of Tehran, Tehran, IRAN \\ ${ }^{3}$ Assistant Professor, Archaeological Research Center, Cultural Heritage Research Center, Tehran, IRAN \\ ${ }^{4}$ Associate Professor, Geophysics Institute of Tehran University, Tehran, IRAN \\ ${ }^{5}$ Ph.D. in Geomorphology \& Environmental Management, Kharazmi University of Tehran, Tehran, IRAN
}

Received: $20 / 03 / 2019$

Accepted: 16/06/2019

\begin{abstract}
Geo-archaeology arises from the integration of methods and abilities of archeology and geomorphology. Evidences suggest that during the history of the earth, climatic conditions have undergone numerous changes in geographic characteristics, including geomorphic ones. Understanding the geomorphic phenomena and its effects on ancient habitats help in identifying human habitation patterns and therefore, managing archaeological heritages in a regional scale. Susiana plain in the north of Khuzestan province has been the longest site of the first and most extensive archaeological research in Iran. Susa, the foundation of the first cultural succession framework, has been introduced from prehistoric periods in southwestern of Iran. Based on the surveys and extensive excavations in Khuzestan, different sites have been identified with long-term occupancies, which in some way illuminate the settlement system of different periods of life in this area. Over a hundred years of excavation in Susa, the signs of settlements and communities have been identified, which prove that these settlements have begun since the middle of the 5th millennium BC, and continued steadily until the seventh century AH. Generally, human and natural changes can be the cause of the weakening of the settlements at any time period. Now, the question is which of these factors has influenced the weakening of the settlements of the western Susiana plain and what process has taken place? The purpose of this research is to investigate the role of the factors affecting these settlements. Susiana plain, as one of the most important human origins in the Middle East, is of great importance to those interested in the natural and ancient sciences. Geoarchaeological studies, and especially the use of geomorphological techniques to understand the pattern of human habitats, can be an effective step towards making the history of civilization clearer in this region, and in Iran. The methods used in this study were application of corona satellite images, field observations and luminescence optical lens experiments. Overall, the survey of the environment, review the totality of settlements and water resources, as a criterion for field deployments, have been used in this study. Therefore, the separation of historic or prehistoric periods is not so significant. Although the role of human factors in undermining certain important settlements is undeniable, but in the vastness of a plain with hundreds of scattered settlements, a greater reason is required. In addition, there is not enough evidence available from anthropologists about human factors yet. If we consider the importance of water in human societies and throughout the human history along with the environmental changes detailed in the discussion, it can be assumed that the natural changes were the main factor in undermining or destroying the
\end{abstract}

*Corresponding author: dr.rezamotamed@gmail.com 
settlements of the western Susiana plain. The overall results show that, contrary to the assumptions, the Dez River plays an important role in the population deployments of the western Susiana plain, which has been abandoned after geomorphologic changes in the bed and as a result of the lowering of the water level, declining the settlements of the plain. Eventually, after an indefinite period of time, with the construction of the Harmushi channel from Karkheh and the expansion of its branches, the settlements were gradually reformed in the western part of Susiana plain.

Keywords: Susiana, Luminescence, Geo-Archeology, Geomorphology, Hydraulic Structures 


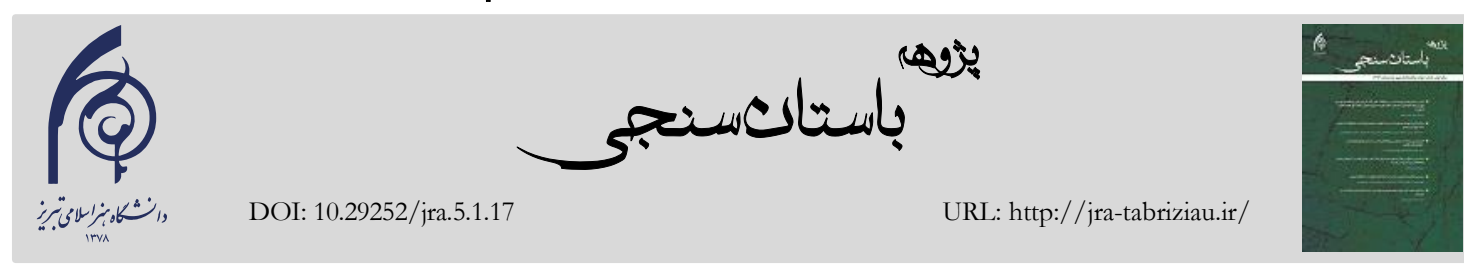

دمالم يَرَوهشى

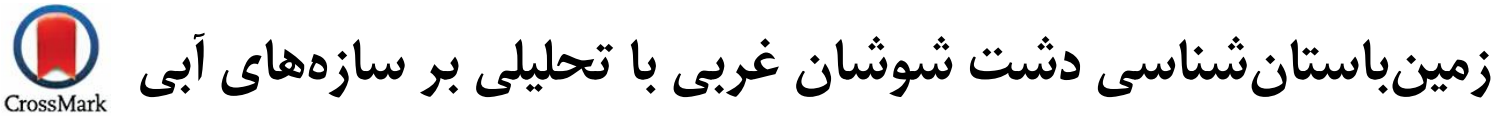

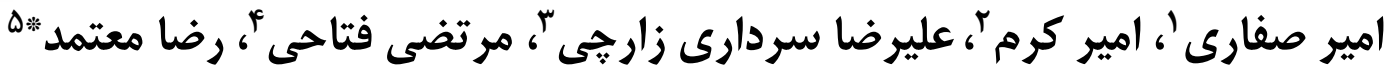

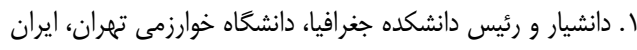

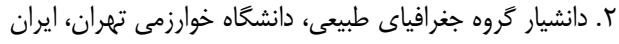

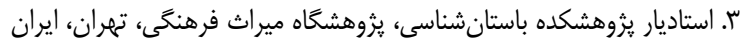

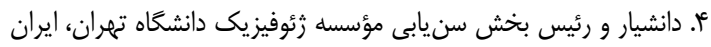

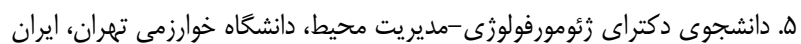

تاريخ يذيرش: وسرس

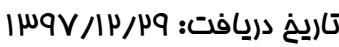

جكيده

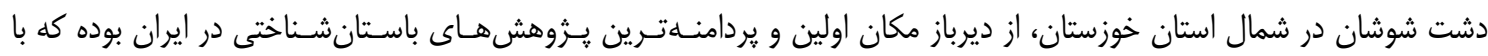

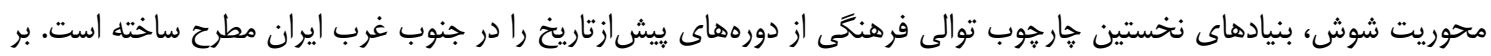

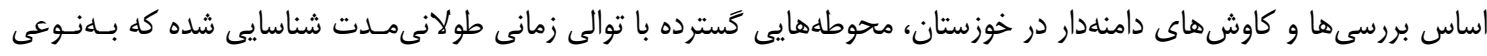

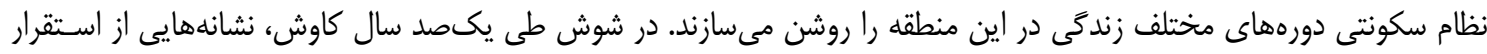

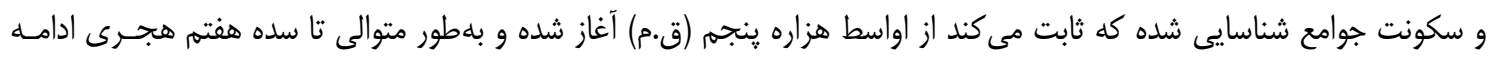

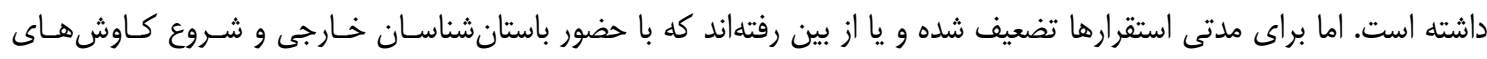

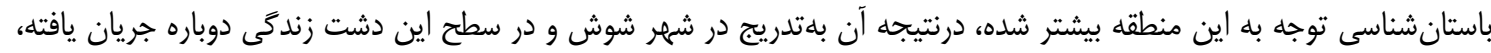

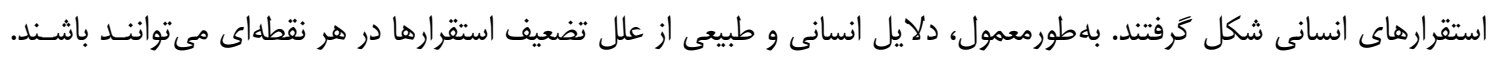

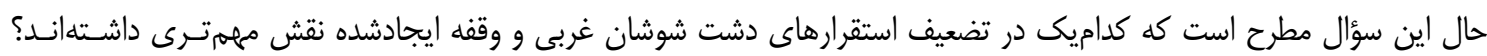

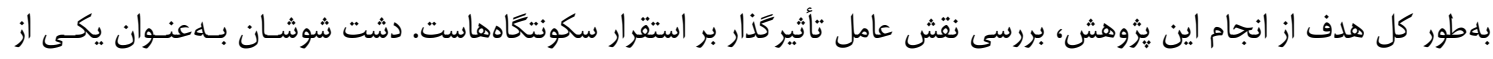

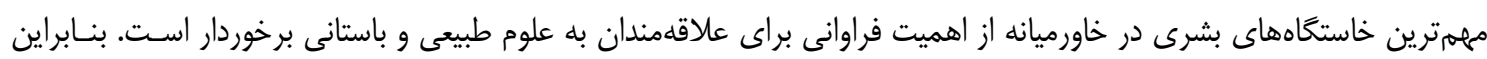

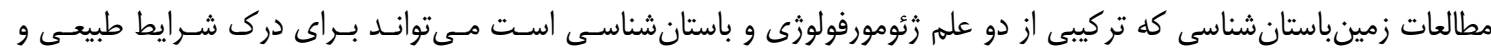

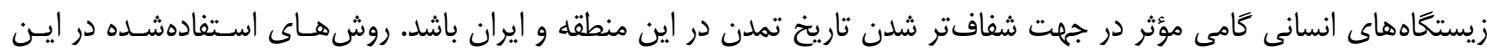

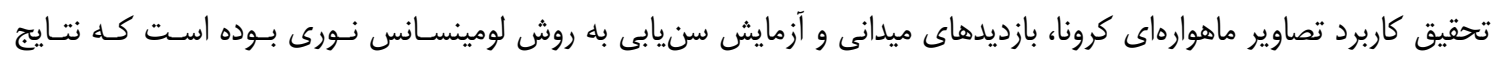

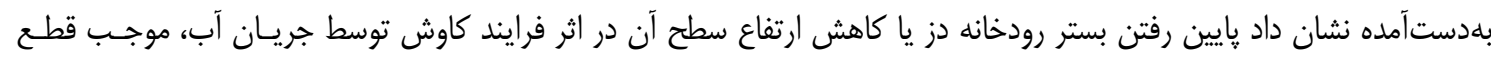

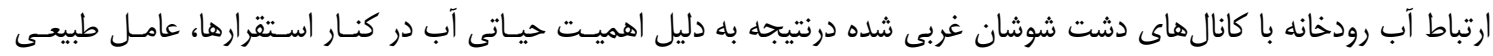

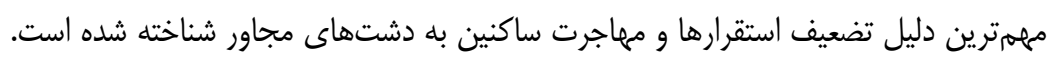

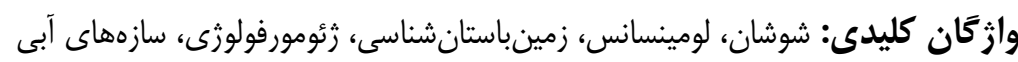

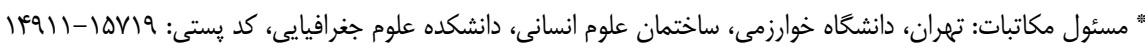

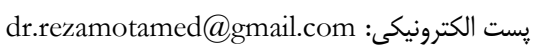

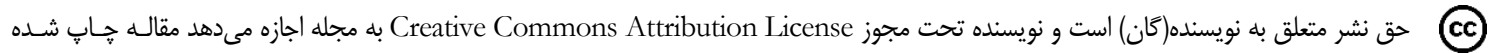
را با ديكران به اشتراك بخذارد منوط بر اينكه حقوق مؤلف اثر حفظ و به انتشار اوليه مقاله در اين مجله اشاره شود. 


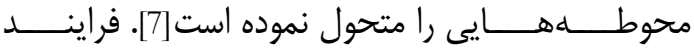

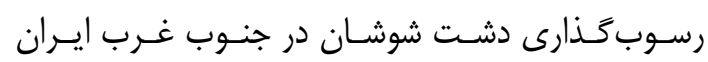

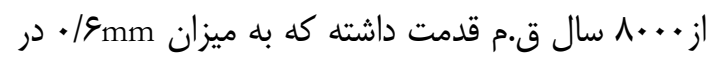

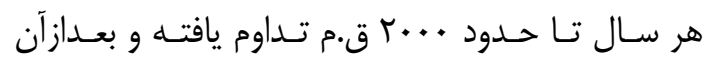

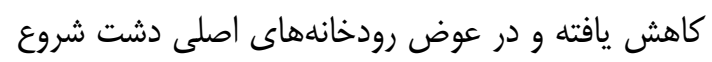

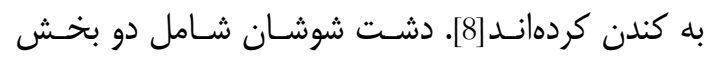

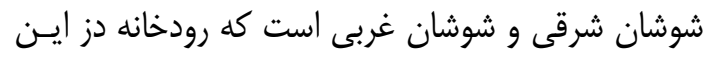

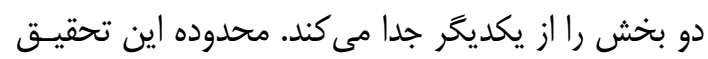
بلهوسيله عوارض طبيعى و انسانى مشخص رَّريده است.

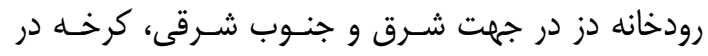

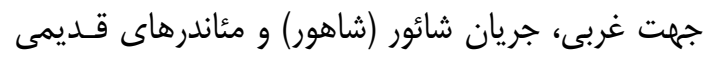

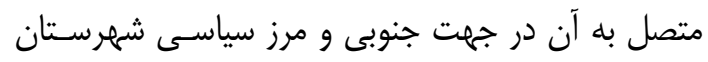

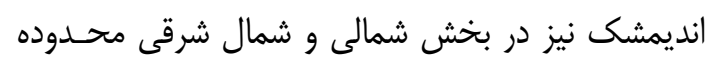

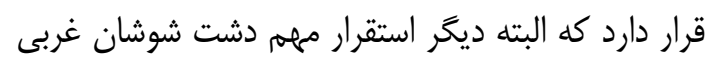

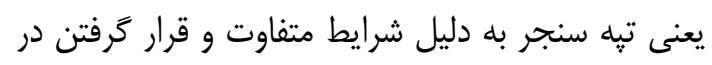

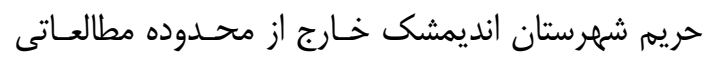
قرار گرفته است (شكل (). در شوش طى يكسصد سال كاوش، نشـانهــايى از

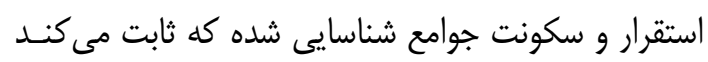

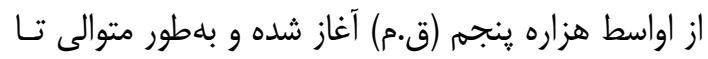

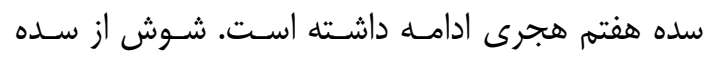

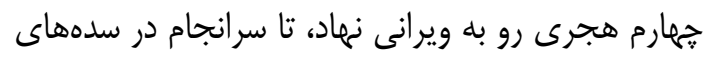

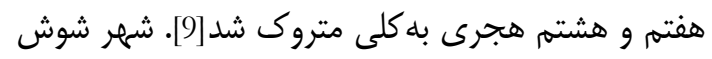

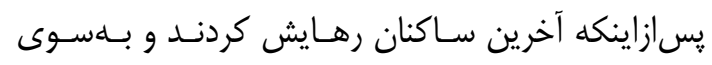

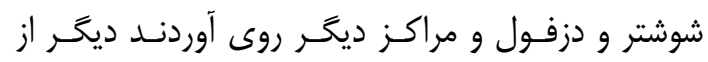

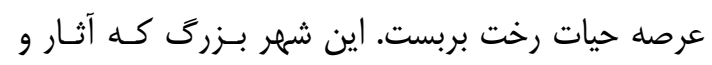

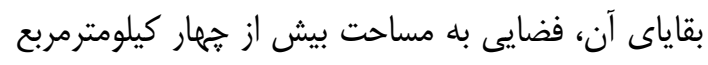

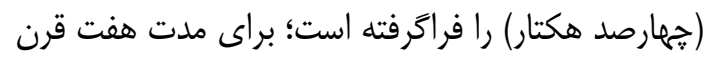

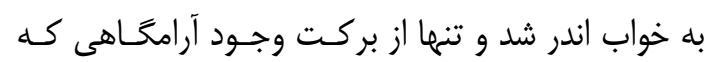

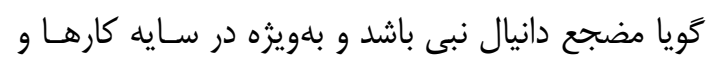

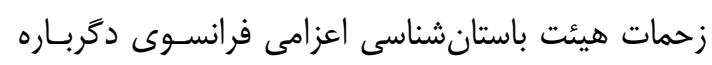

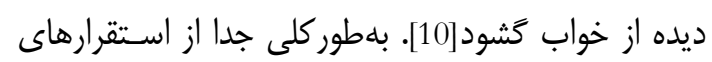

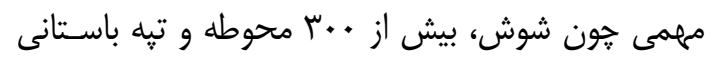

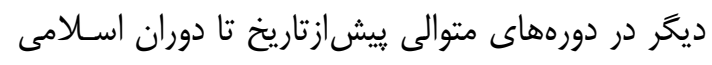

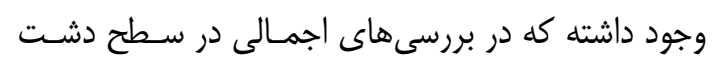

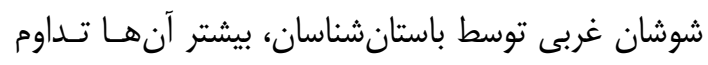

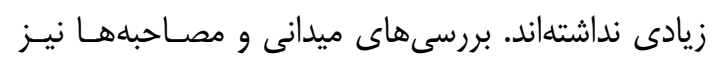

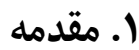

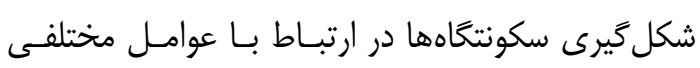

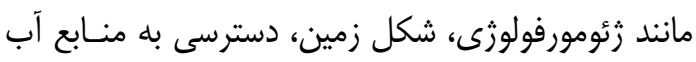

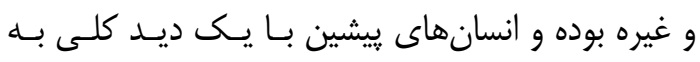

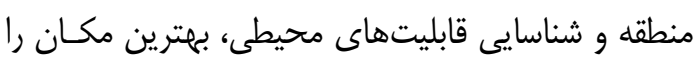

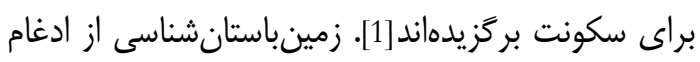

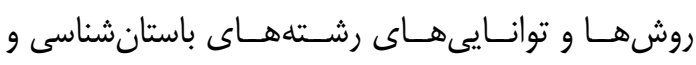

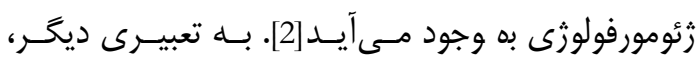

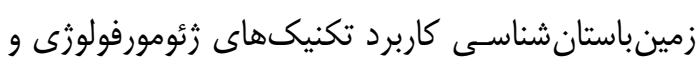
زمينشناسى در باستانشناسى و مطالعه تعامل انسانهـا با محيط طبيعى در مقيـاسهــاى زمانى و مكانى متعدد است[3]. شواهد نشان مى دهد كه در طول تاريخ زمـين،

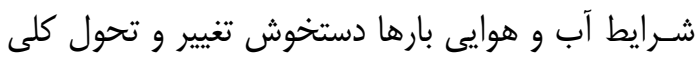

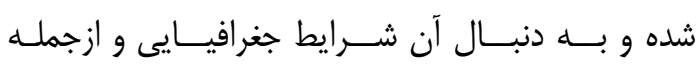

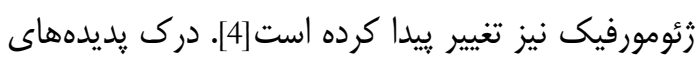

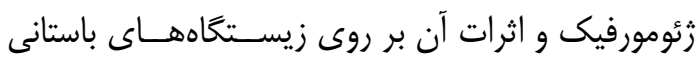

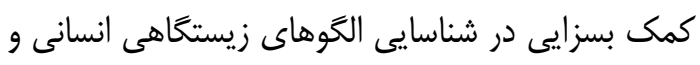

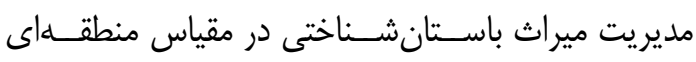

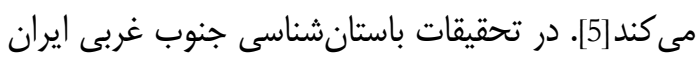

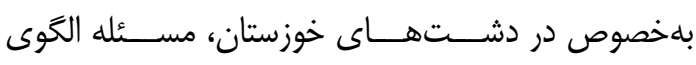
استقرارى، ترك و جابجايى زيستخاههـا، تـأثيرات محيط ديط دئان

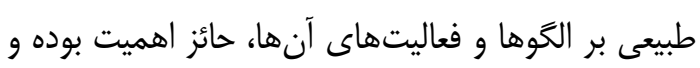

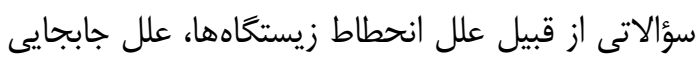
زيستخاهها و تأثيريذيرى از محيطهـاى إنى طبيعى در دوران

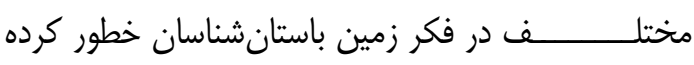
است]6]. دشت شوشان در شــــــمال استان خوزستان، از

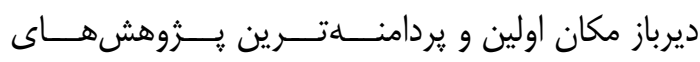

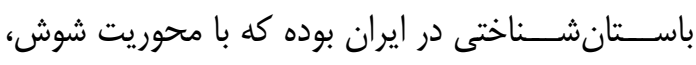

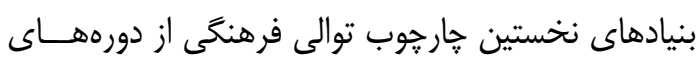
ييشازتاريخ را در جنوب غرب ايران مطرح ساخته است. بر اساس بررسىها و كاوشهـاى دامنـهدار در خوزستان،

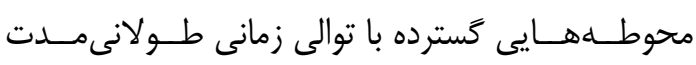

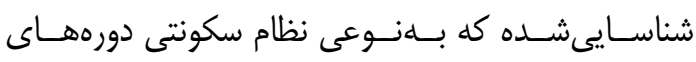

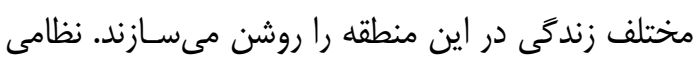
كه برآمده از كشش زيستمحيطى غنى ونى و منابع گسترده،

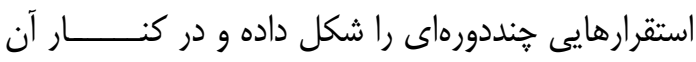

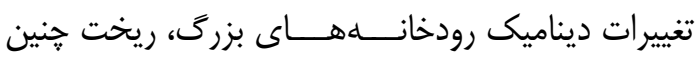

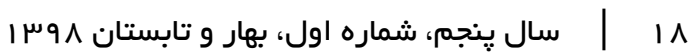




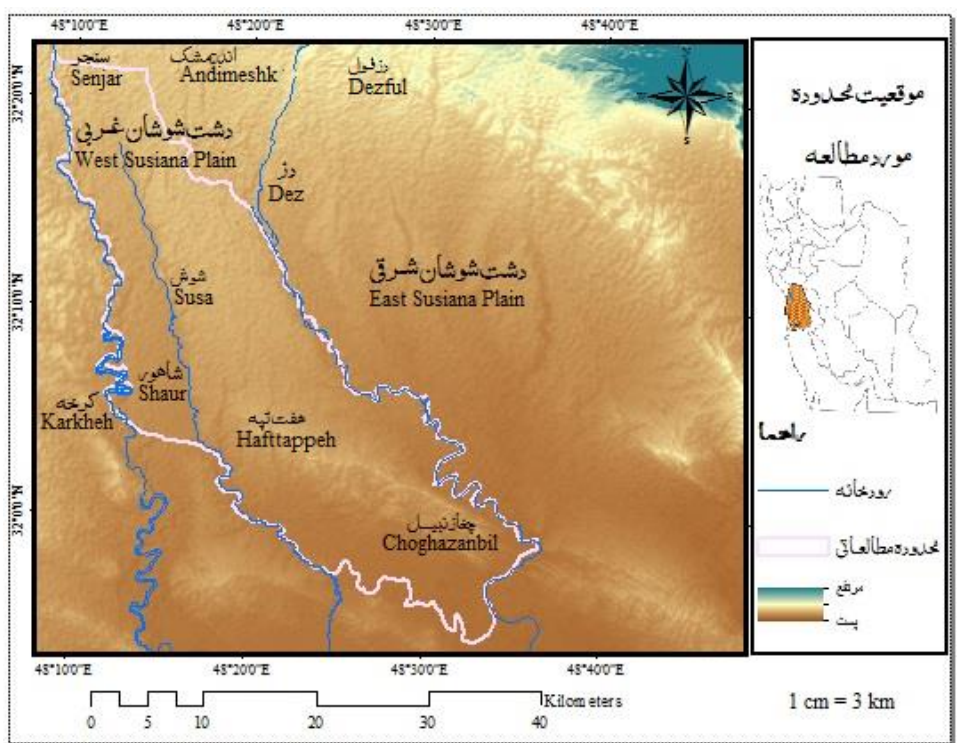

شكل ا. موقعيت محدوده موردمطالعه

Fig 1. Studied area Location

\section{r. ضرورت انجام تحقيق}

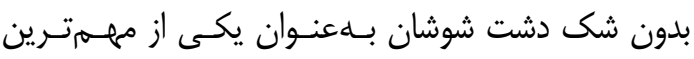

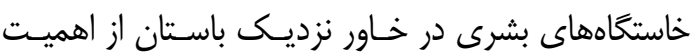

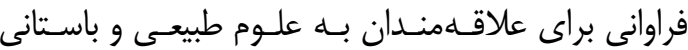

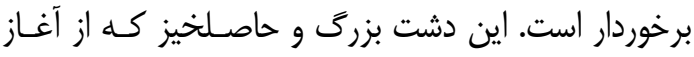
استقرارهاى روستانشينى در عصر نوسـنكى تـا بــه امـروز ميزبان اقوام و گروههاى مختلفى بـوده، شـواهدى از آثـار

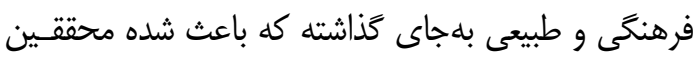

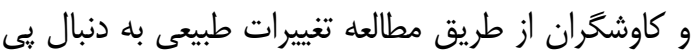
بردن به شرايط طبيعى دوران كذشـتهاه، و برخسى ديخـــ از

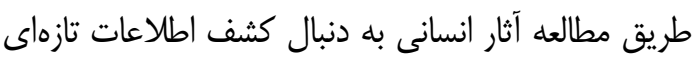

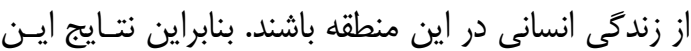
تحقيقات از اهميت خاصى برخوردار است.

\section{". بيشــينه تحقيـق}

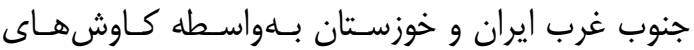
باستانشناسى شوش در اواسـط و اواخــر قـرن نـوزدهم

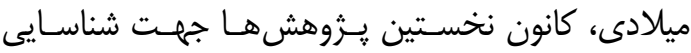
شهرهاى باستانى و تحولات فرهنگى جوامع ييشازتاريخ تا معاصر بوده است[9]. اين كاوشها در سده بيسته نيـز

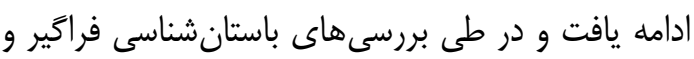
كسترداى كه در سراسر دشت شوشان انجام شد، بـيش
نشان مىدهد كه اغلب روستاهاى امروزى سـطح دشـت

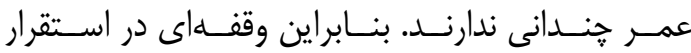

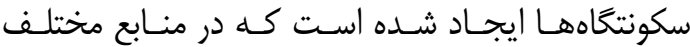
باستانشناسى به اين موضوع توجه داشتهاند و در بالا بهابه

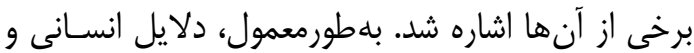

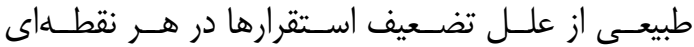

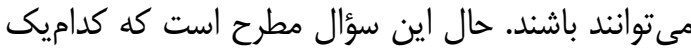
در تضعيف استقرارهاى دشت شوشان غربى اثر كذار بوده و جه فرايندى طى شده است؟ بررسىهاى كتابخانهاى و ميدانى نشان مىدهد كه بين دو عامل اصلى در تضعيف

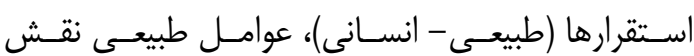
يررنختـرى داشتهاند. به نظر مسىرســ فرسـايش بسـتر

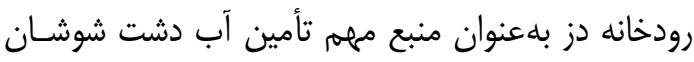

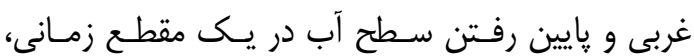

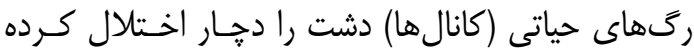

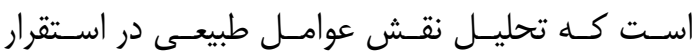

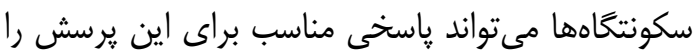

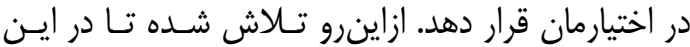
يزوهش از طريق بازديـدهاى ميـدانى، بررسى تصـاوير

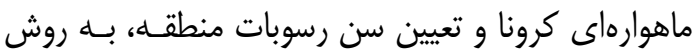
سنيابى لومينسانس نورى به پاسخى روشن در اين مورد

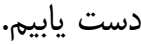

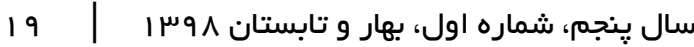


عوارض باقيمانده و موقعيـت عــوارض تخريـبـشــه بــهـ دست آيد.

\section{r-r}

در اين تحقيق بازديدهاى ميدانى طبق برنامهريزى قبلى

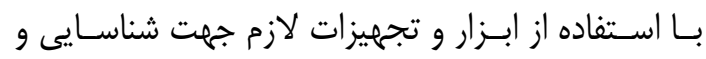
برداشت نمونهها انجام شـده است. شناسايى اوليه منطقه

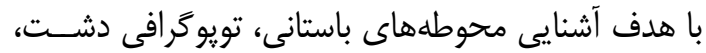

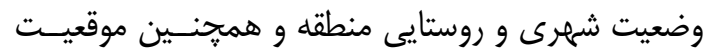

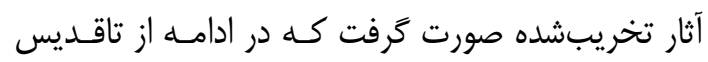

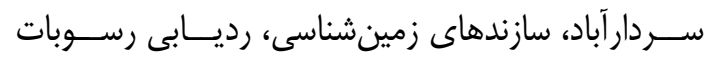

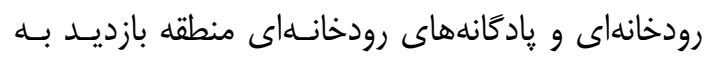

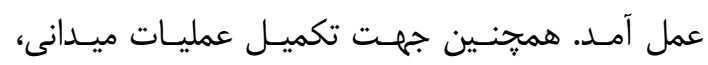

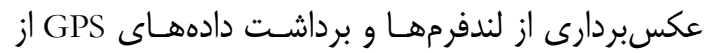

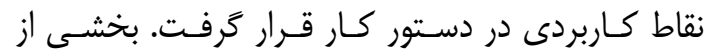

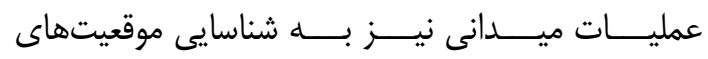

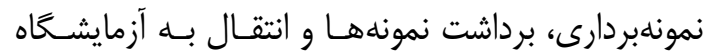
سنيابى اختصاص يافت (شكل r).

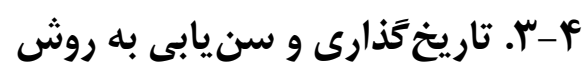 لومينسانس نورى (OSL)}

بــا اسـتفاده از روش لومينسـانس نـورى، آخــرين زمــان نورخوردى رسوب تخمين زده مىشود. در اين تحقيـق،

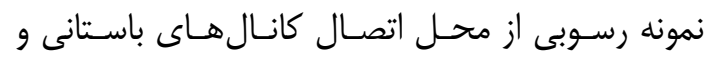

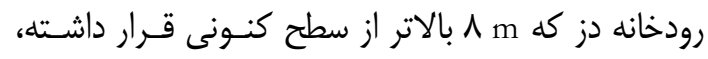

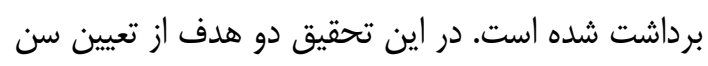

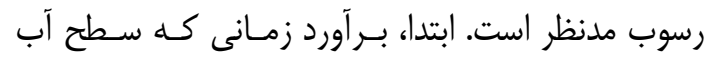

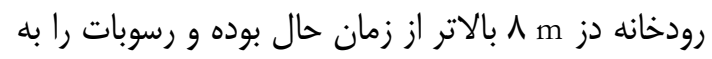

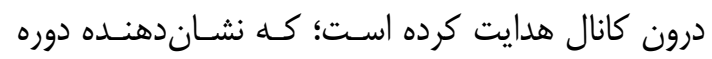

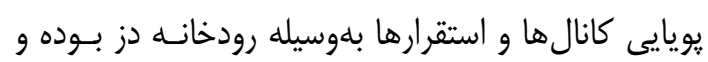
دوم، بررسى ميزان فرسايش (كندن) در بستر رودخانه دز

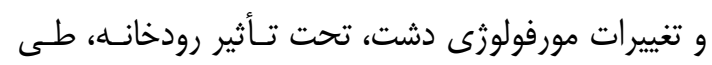

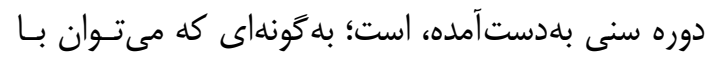

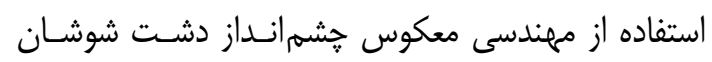

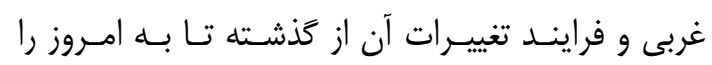
بازسازى كرد.

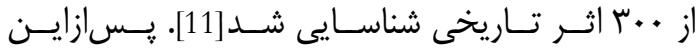
بررسى ها، يزوهشهاى ميانرشتهاى باستانشناسـى نيـز بلهمنظور شناخت تغييرات زمينباستان شناسى اين منطقه

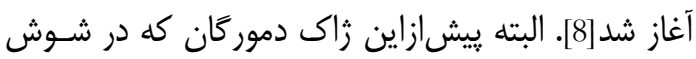
كاوشهاى باستانشناسى آغاز كـرده بــود، بـا مطالعـات

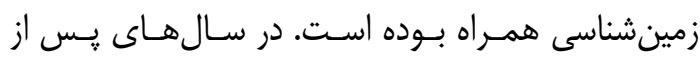

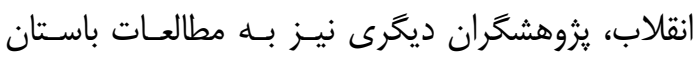

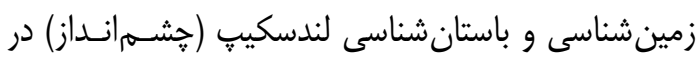

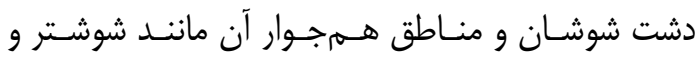

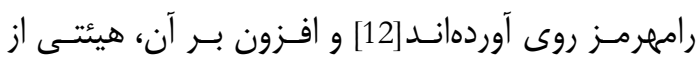

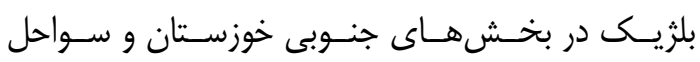

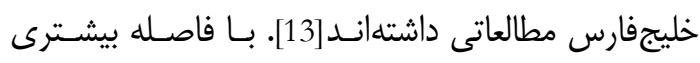

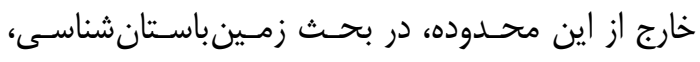
مقصودى و همكاران نقش مخروطافكنههاى جاجرود در دشت تهران و حاجى عرب در دشت قزوين بـر اسـتقرار

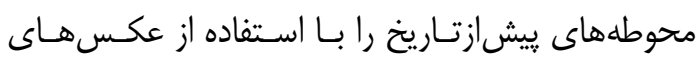

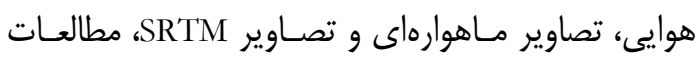
ميدانى موردبررسى قرار دادند[14]. در تحقيقـاتى ديخـر، تصوئ

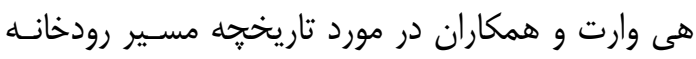

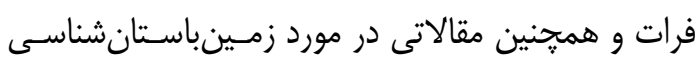

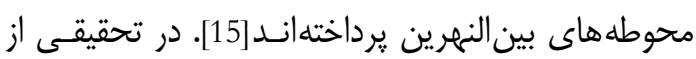

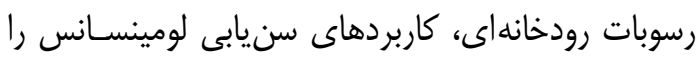

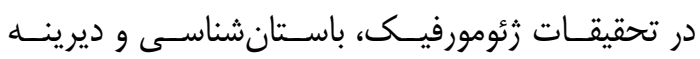
لرزهناسى ارائه داد[16].

\section{F. P. روش تحقيـق

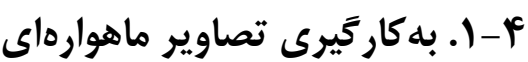

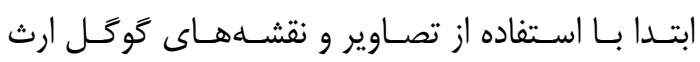
محدوده موردمطالعه مشخص و تعيين حدود شد. سـيس

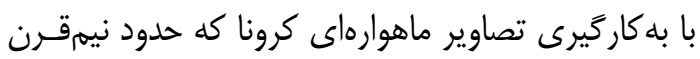
ييش در اواخر دهه • عبا برداشت شـده، آخـرين آثـار و

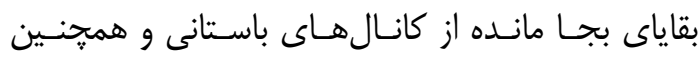

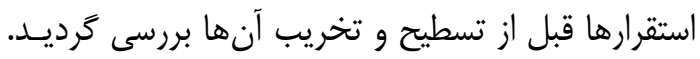

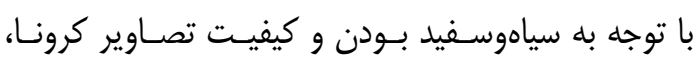

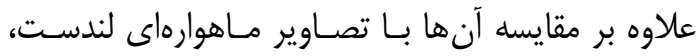

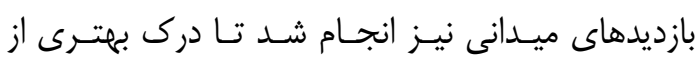




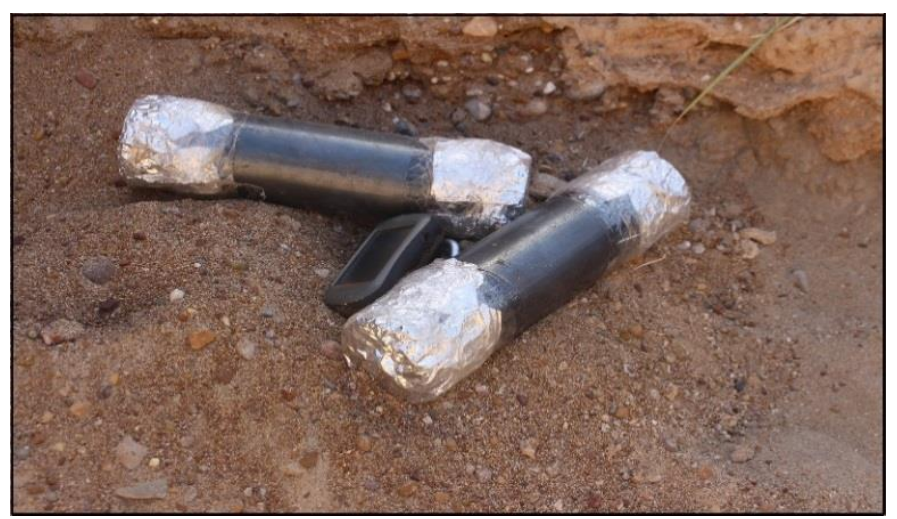

شكل ז. نمونهَيرى از رسوبات آبى جهت انجام آزمايش سنيابى

Fig 2. Sediment sampling for age testing

اليكوتهاى مربوط بــه نمونـه، پـس از آمـادهسـازى، در

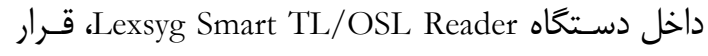

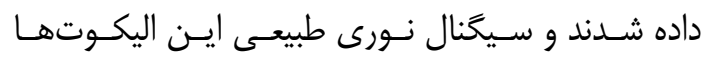

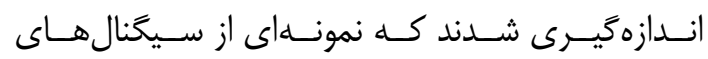

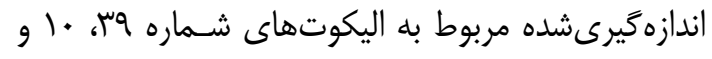

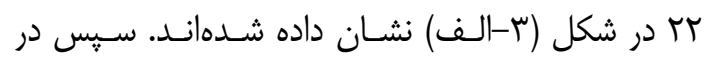

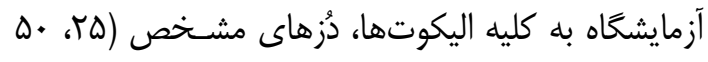

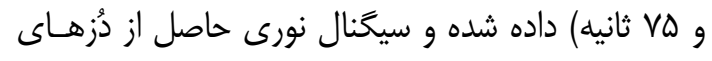

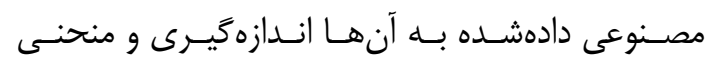

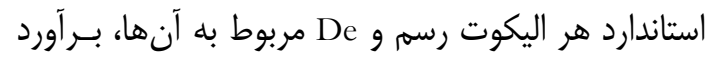

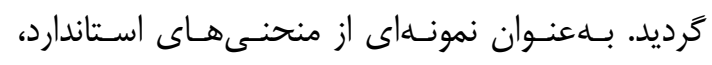

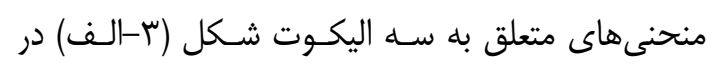

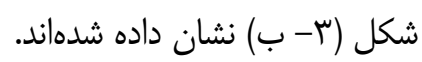
در ادامه، دُز سالانه، محاسبه و با تقسـيمه دُز معـادل

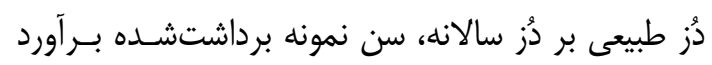

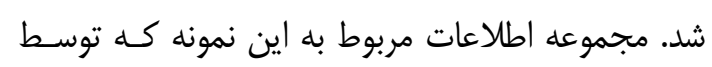

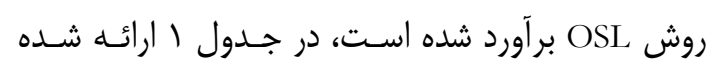

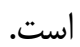

\section{ه. تحليل يافتهها - مافها} ه-1 هاقديس سردار آباد

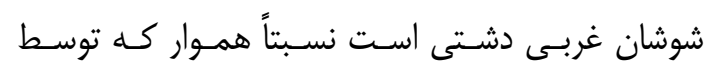

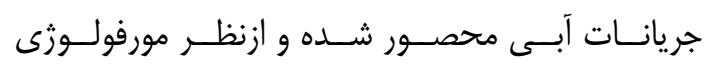

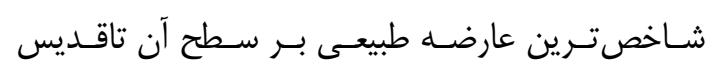

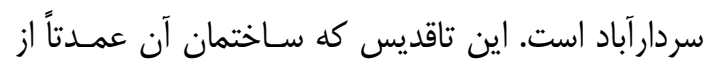
سازند آغاجارى تشكيل يافته، در محـدوده موردمطالعـه،

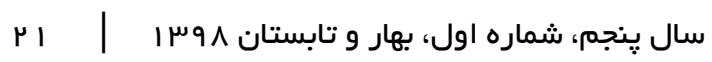

جهت برآورد سن هـر نمونسه، مقـادير دُز معـادل دُز

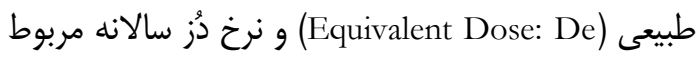

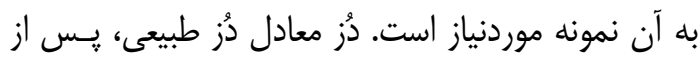

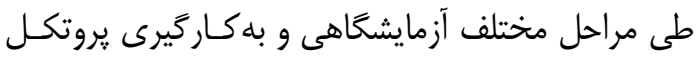

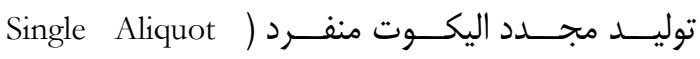
(Regeneration: SAR برآورد مىشود. نرخ ذُز سالانه، نيز

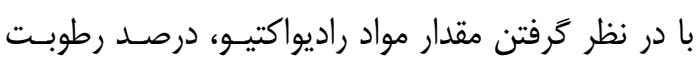

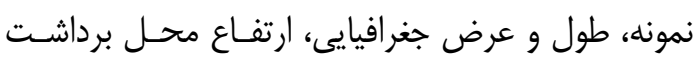

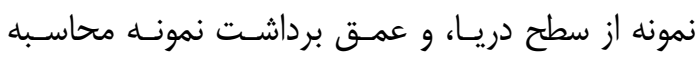

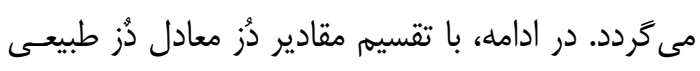

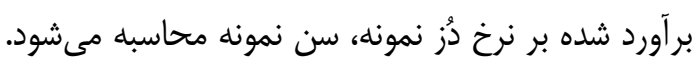

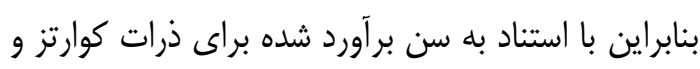

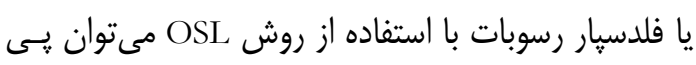

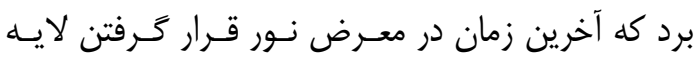

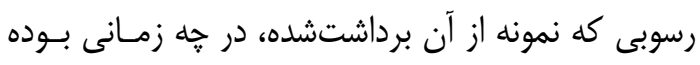
است. در اين تحقيق، پس از از عمليات نمونهبردارى، نمونه

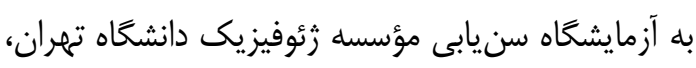

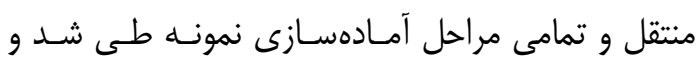

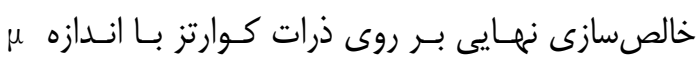

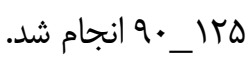

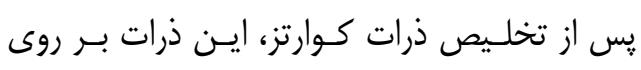

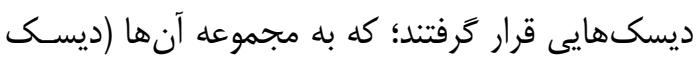
و ذرات روى آن)، اليكوت كَفته مى شود. از تعداد بيش از ازئل

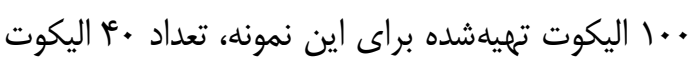

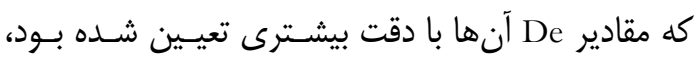

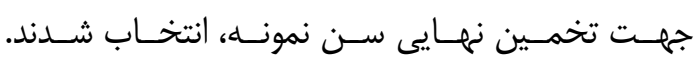




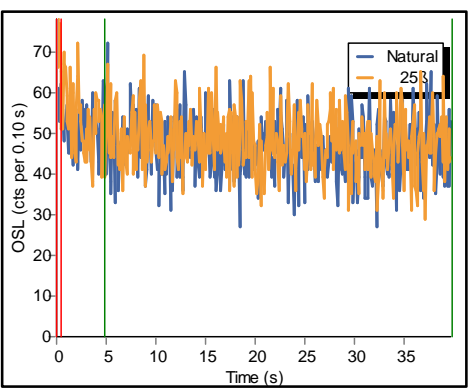

سيخنال نورى مربوط به اليكوت شماره كاه Light signal related to Aliquot No.22

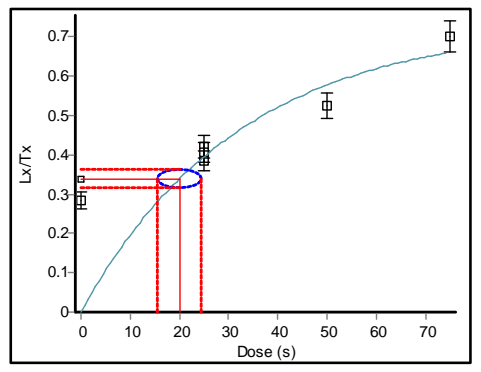

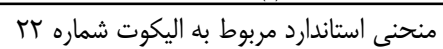
Standard curve for Aliquot No.22

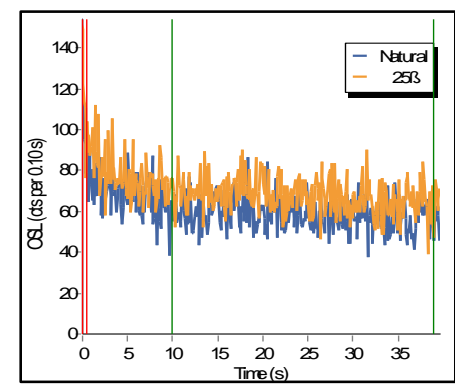

10 سيخنال نورى مربوط به اليكوت شماره Light signal related to Aliquot No.10

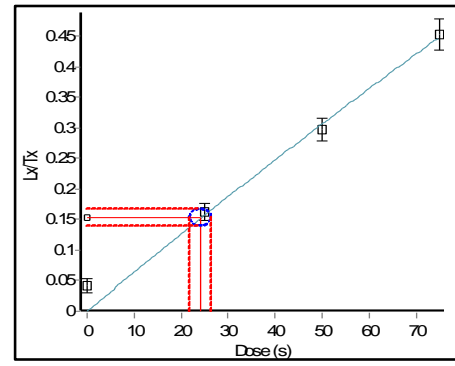

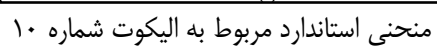
Standard curve for Aliquot No.10

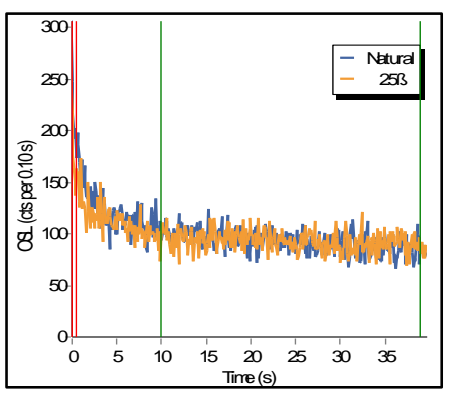

الف. سيخنال نورى مربوط به اليكوت شماره وج" Light signal related to Aliquot No.39 .a

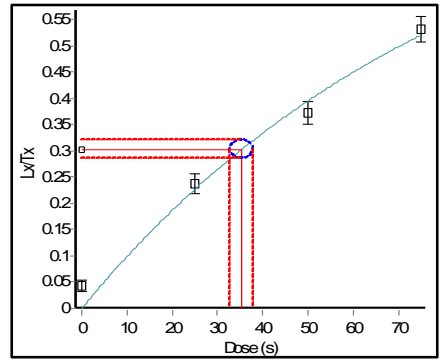

ب. منحنى استاندارد مربوط به اليكوت شماره هو هو .b Standard curve for Aliquot No.39

شكل r. سيخنال ها و منحنى هاى سه اليكوت نمونه برداشتشده

Fig 3. Samples signals and curves of three Aliquots

جدول ا. مقادير استفادهده جهت سنيابى و سن نهايى نمونه برداشتشده

Table 1. Used Values for Age testing and samples final age

\begin{tabular}{|c|c|c|c|c|c|c|c|c|c|c|}
\hline $\begin{array}{l}\text { Sample } \\
\text { ID }\end{array}$ & $\begin{array}{c}\text { Grain } \\
\text { Size } \\
(\mu \mathrm{m})\end{array}$ & $\begin{array}{c}\text { Water } \\
(\%)\end{array}$ & $\begin{array}{l}\text { Depth } \\
\text { (m) }\end{array}$ & $\begin{array}{c}\mathrm{K} \\
(\%)\end{array}$ & $\begin{array}{c}\mathrm{U} \\
(\mathrm{ppm})\end{array}$ & $\begin{array}{c}\text { Th } \\
\text { (ppm) }\end{array}$ & $\begin{array}{c}\text { Cosmic } \\
\text { (Gy/ka } \\
\text { ) }\end{array}$ & $\begin{array}{c}\text { Total } \\
\text { (Gy/yr } \\
\text { ) }\end{array}$ & $\begin{array}{l}\text { De } \\
\text { (Gy) }\end{array}$ & $\begin{array}{l}\text { Age } \\
\text { (ka) }\end{array}$ \\
\hline M23 & $90-125$ & 5.00 & $\begin{array}{c}4.00 \pm 0 \\
.20\end{array}$ & $\begin{array}{c}0.66 \pm 0 \\
.05\end{array}$ & $\begin{array}{c}0.90 \pm \\
0.05\end{array}$ & $\begin{array}{c}1.31 \pm \\
0.16\end{array}$ & $\begin{array}{c}0.12 \pm 0 \\
08\end{array}$ & $\begin{array}{c}1.06 \pm 0 . \\
09\end{array}$ & $\begin{array}{c}2.50 \pm \\
0.12\end{array}$ & $2.37 \pm 0.23$ \\
\hline
\end{tabular}

قبيل تودههاى حجيم و لايلمبندى شده ماسـاءى، شـنى،

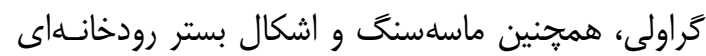

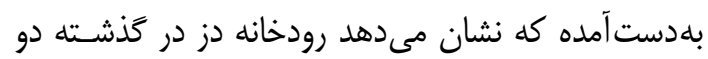

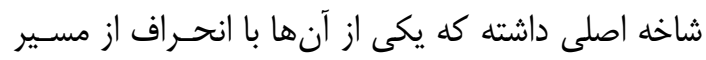

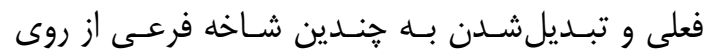

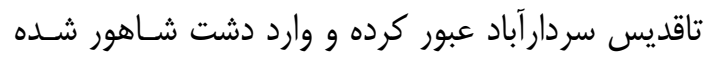
است (شكله)، كه بهتدريج از تعداد شاخههاى فعال اين

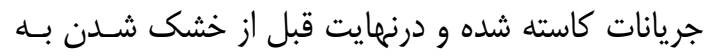
يك يا دو شاخه فعال تبديل شدهاند.

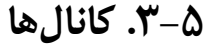

بررسى تصاوير ماهوارهاى كرونا كه آخرين آثار بجا مانده

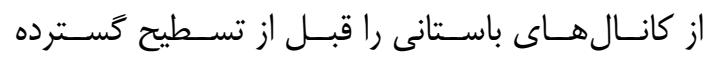

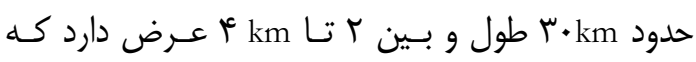
ارتفاع آن در محدوده A تقريباً همسطح با دشت و همين

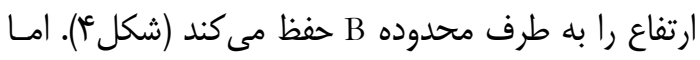

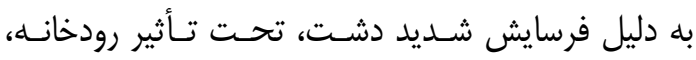

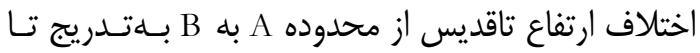

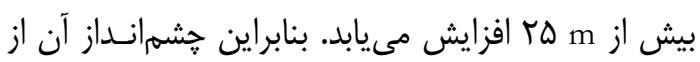

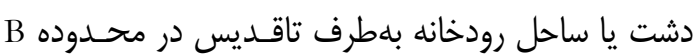

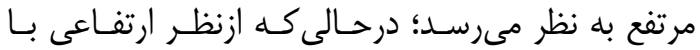
محدوده A تفاوت جندانى ندارد.

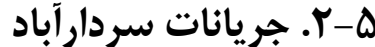

در بررسىهاى ميدانى بر روى تاقديس فرسايش يافتهى

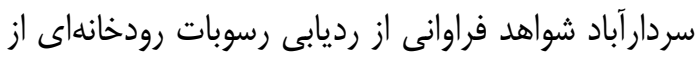




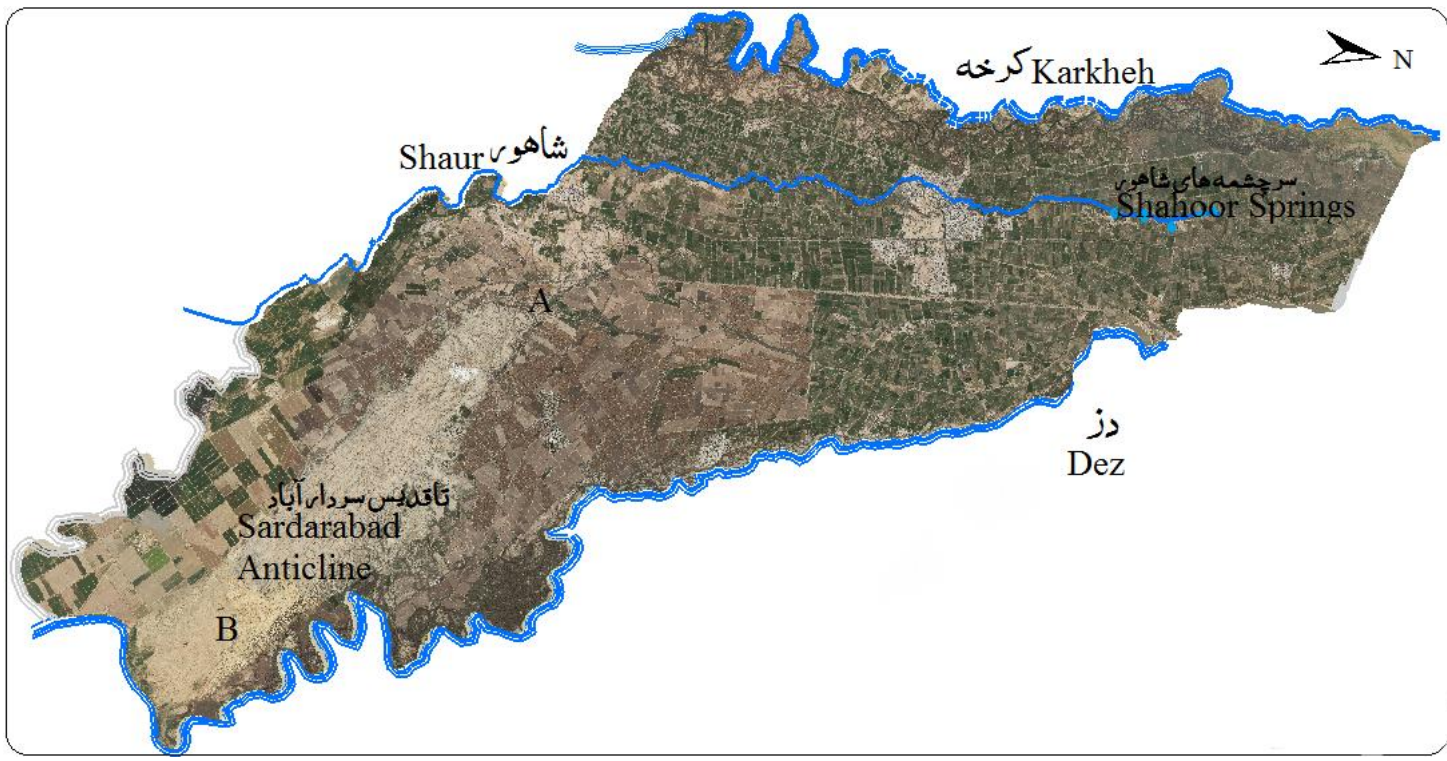

شكل f. موقعيت تاقديس سردار آباد در دشت شوشان غربى

Fig 4. Sardarabad Anticline Location on the West Susiana plain

طرفى نيز بـه دليـل فرسـايش زيـاد و كيفيـت تصـاوير،

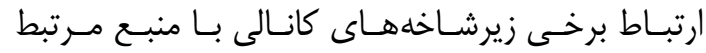

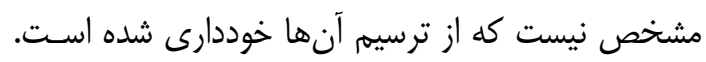

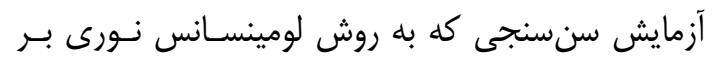
روى رسوبات، در محل تلاقى كانال و رودخانه دز انجـام

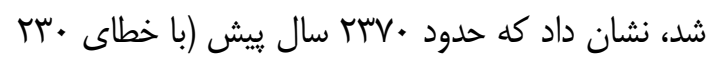

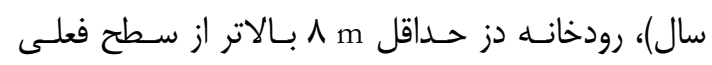
جريان داشته و با كانالها در ارتباط بوده است.
زمينهـاى دشـت بـهمنظـور توسعله كشـاورزى نشـان

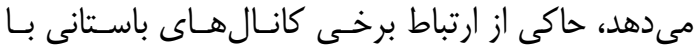

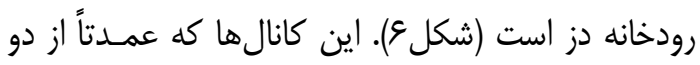
منطقه تغذيه شدهاند تا اطراف شوش و هفتتبـهـ امتـداد يافته و در سطح دشت يراكنده شدهاند. البته الكَوى آنها كه از تصاوير كرونا استخراج شده و در اشكال زير آمـده،

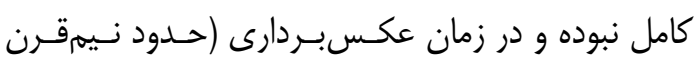

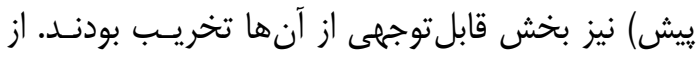

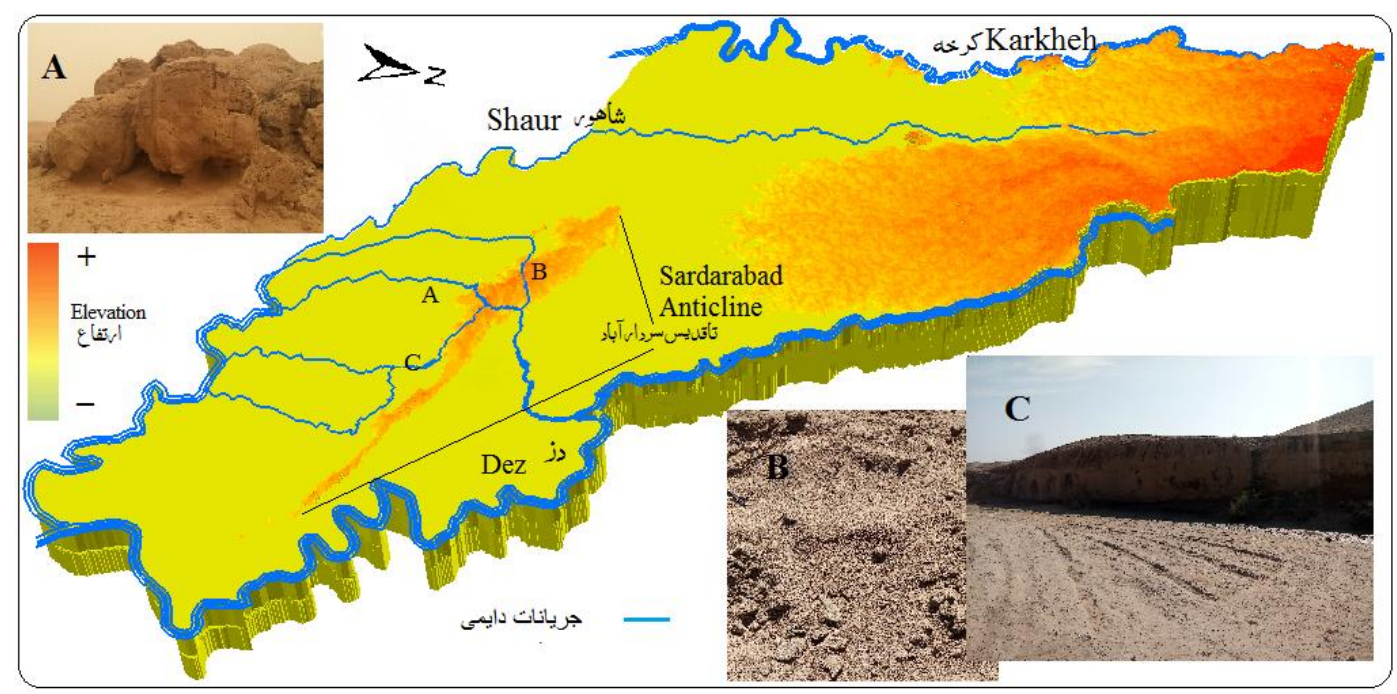

شكله. جريانات سردارآباد و آثار يافت شده

Fig 5. Sardarabad streams and found Evidence 


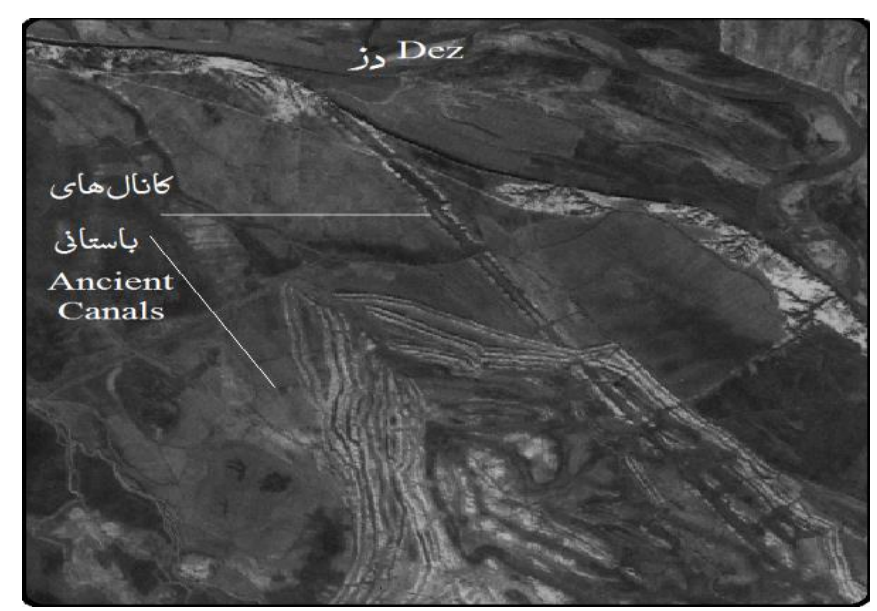

شكل و. الكوى هرمى و خطى كانال هاى باستانى در كنار رودخانه دز

Fig 6 Ancient canal Pyramid and Linear Pattern of along the Dez River

است كه اخيراً آثار قناتهايى يافت شده كه احداث اولين

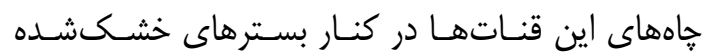

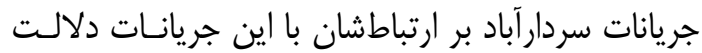

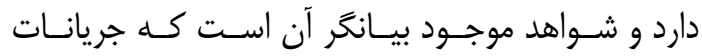
سردارآباد دست كم تا دوره ساخت قنات توسط انسان كه برخى باستان شناسان و مورخين به دوره ساسانيان نسبت

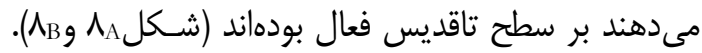
بلهعبارتديخر، جريانات سردارآباد ازنظر طبيعى، حداقل از باز زمان احداث قناتها به عقبتر (قبل از احداث زيخــورات

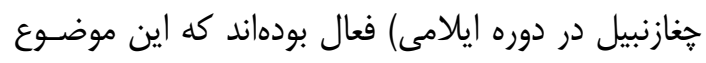

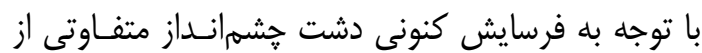
تويوگرافى منطقه را براى ما ترسيهم مى كند.

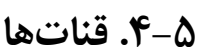

در دشت شوشان بزرى (از دشت بهببهان تا بخشهـايى از ايلام) تفاوت بارزى بين قناتهاى اين دشت و ايـران مركزى وجود دارد. در فلات ايـران اغلـب قنـاتهـا آب آبـان

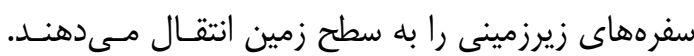

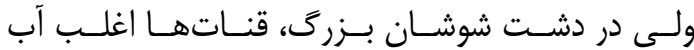

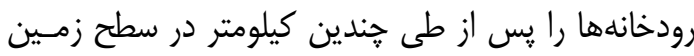

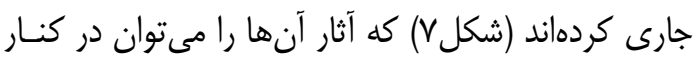

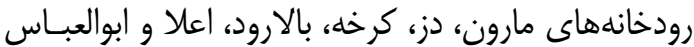

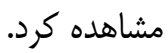
بنابر اين رودخانه، تنها منبع تأمين آب اين كونه قنـاتهـا بوده است. اهميت قناتها در اين يثوهش از ايسن بابست

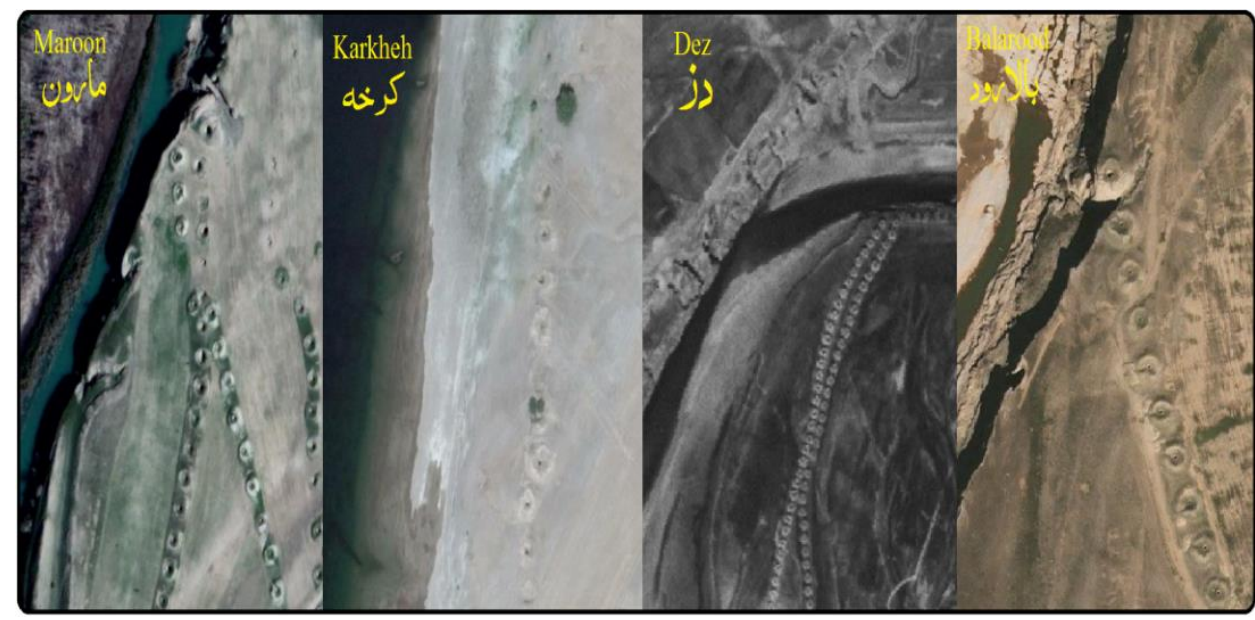

شكل V. قناتهاى رودخانهاى در دشت شوشان بزرى

Fig 7. Great Susiana plain Qanats (rivers provide these qanat water) 


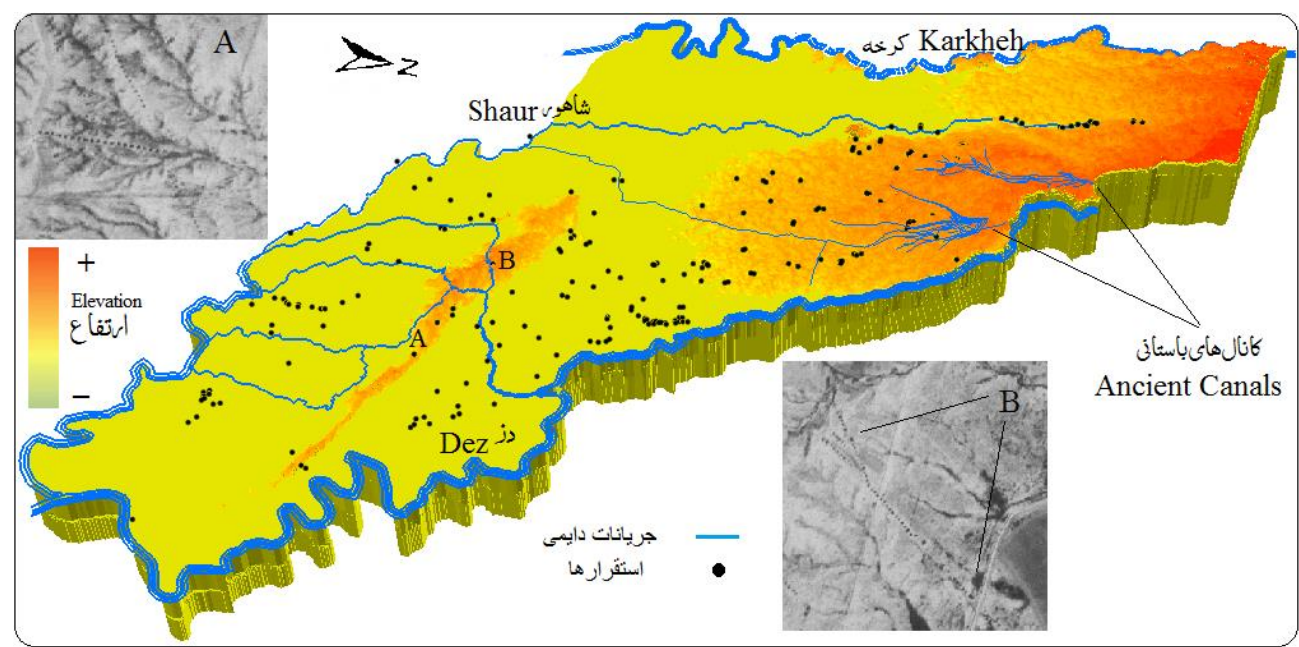

شكل ^. احداث سازههاى آبى (كانال - قنات) و افزايش استقرارهاى انسانى (موقعيت استقرارها با نقطههاى سياه مشخص شده است)

Fig 8. Hydraulic structures Construction of (qanat and canal), increased human settlements (black points show settlement Location)

محوريت شوش از دوران نوسـنكى تـا اسـلامى وجـود

داشته است.

\section{ه-8. يُايين رفتن سطح رودخانه دز و تأثير بر}

\section{استقر ارها}

رودخانه دز كه بهمرورزمان با كندن، بستر خود را يـايين

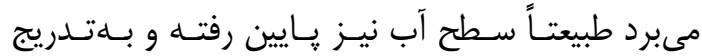

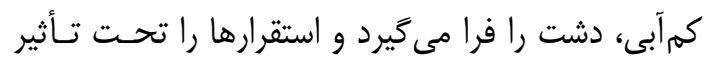

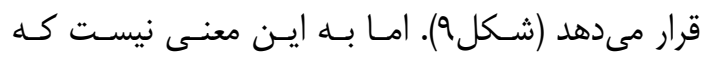

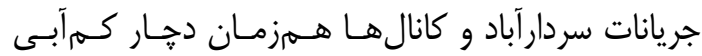

ه-ه. شكل فيرى استقر ارها

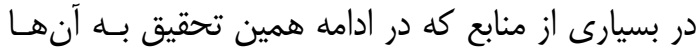

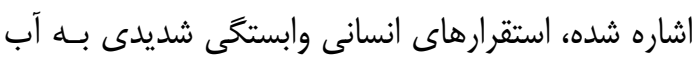

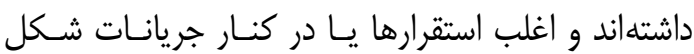

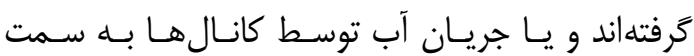

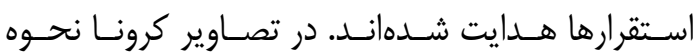

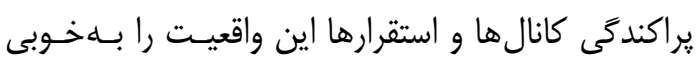
منعكس مى كند و اغلـب اسـتقرارهاى دشـت در فاصـله كمتر از m . - r نسبت به كانال ها يا نهرها واقع شدهاند.

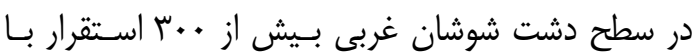

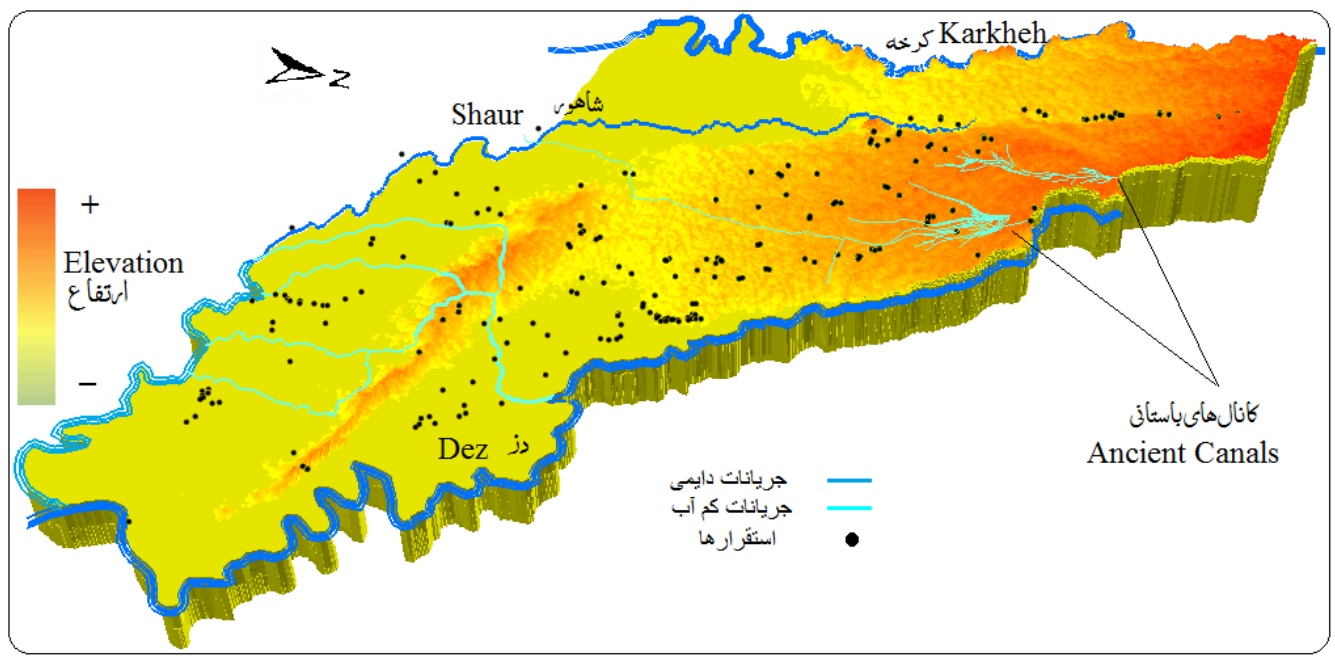

شكله. بإيين رفتن سطح رودخانه دز و كمَآبى در سطح دشت

Fig 9. Decreased Dez river water level and Decreased water volume on the plain

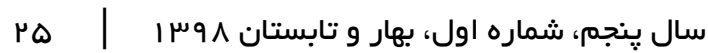




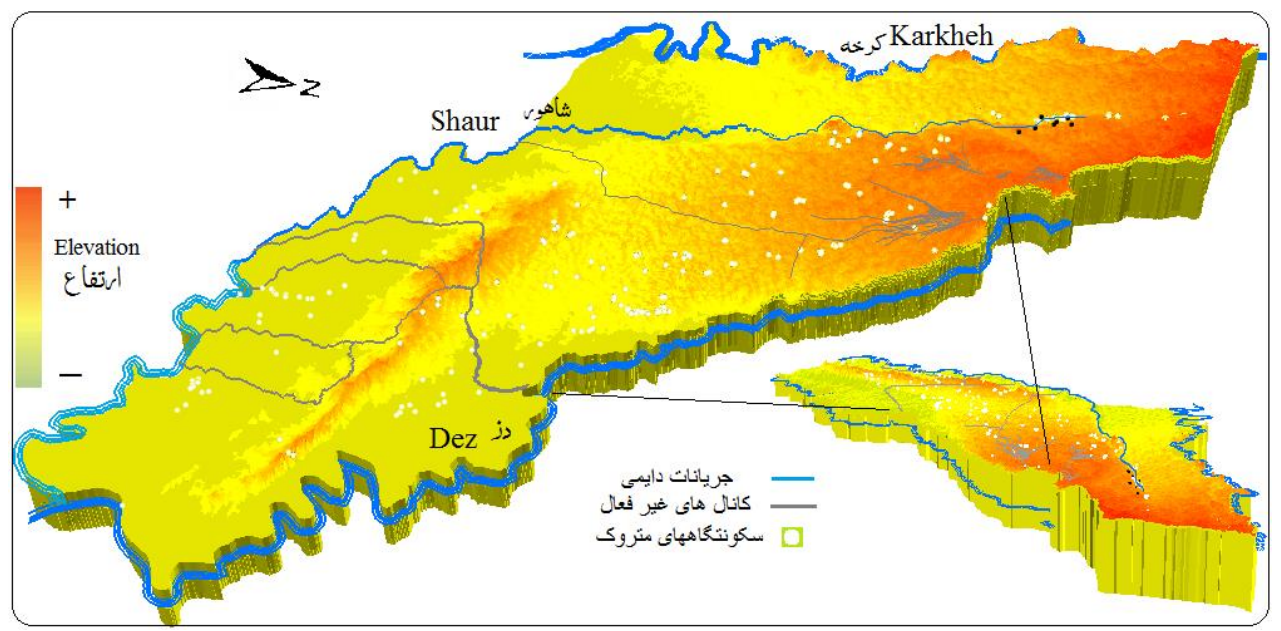

شكل • •. پايين رفتن سطح رودخانه دز، قطع ارتباط با سازهها و جريانات سردارآباد و از بين رفتن استقرارها

Fig 10. Decreased Dez river water level resulting, hydraulic structures and Sardarabad streams disconnection and finally settlements destruction

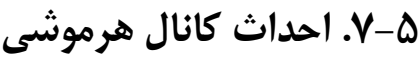

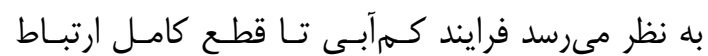

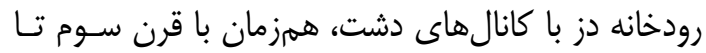
هفتم هجرى بوده است؛ كه بعـد از وقفـهاى در اسـتقرار

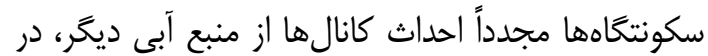

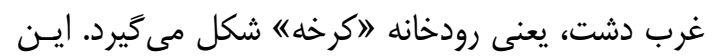

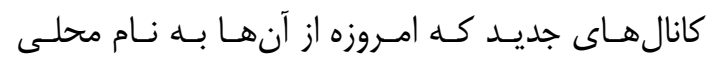

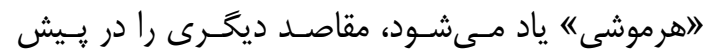

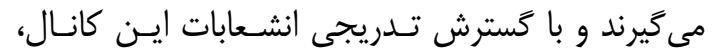

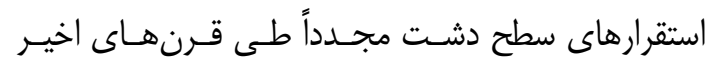

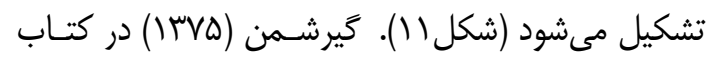

شدهاند. بلهور كلى وابستخى حياتى و دسترسى استقرارها

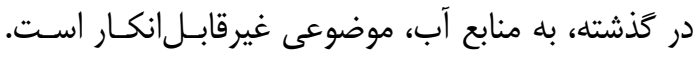

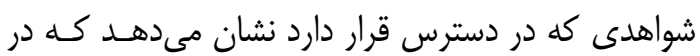

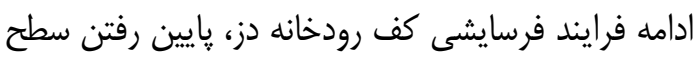

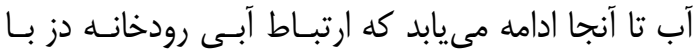

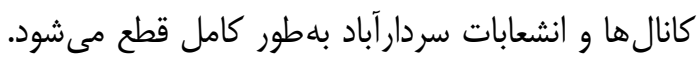

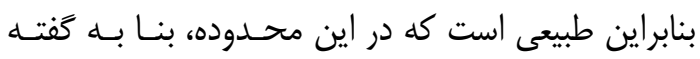
برخى باستان شناسان كه به خالى شدن شوش از سـان إنها

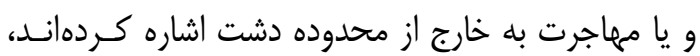

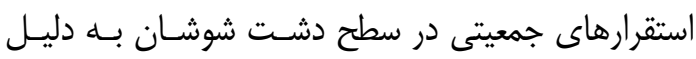
عدم دسترسى به آب با مشكل مواجه شوند (شكل •().

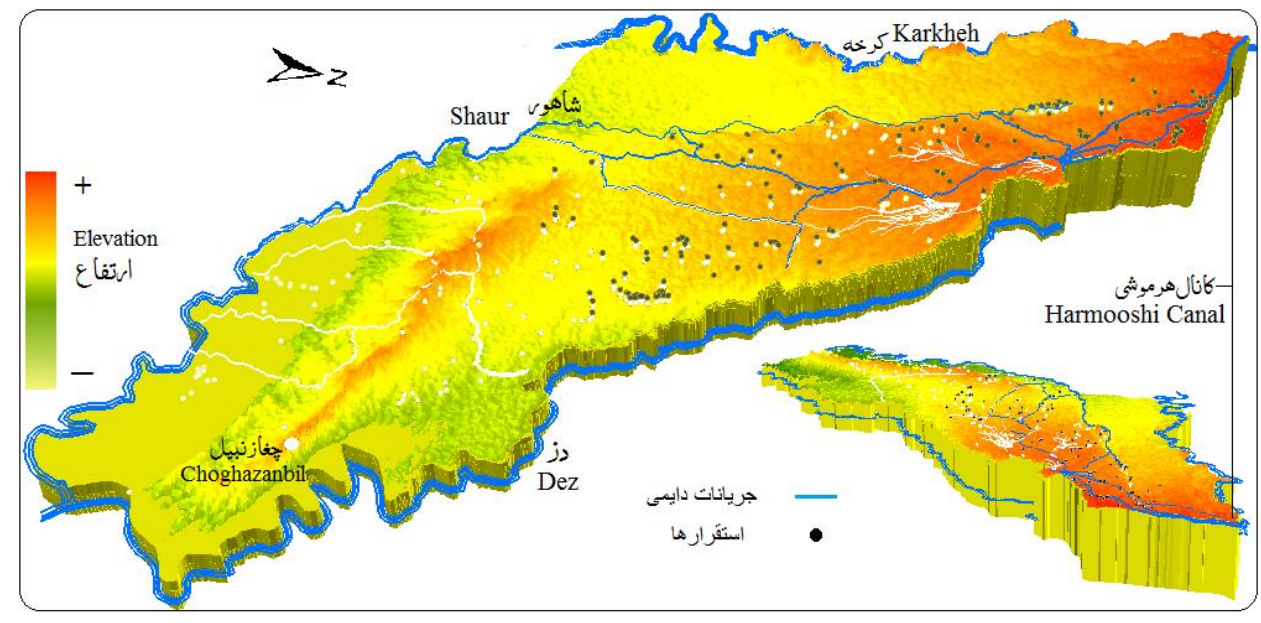

شكل II. احداث كانال هرموشى، شكل

Fig 11. Harmooshi Canal Construction: reformation of settlements 
را به سطح دشت با دبى نسبتاً بالا انتقال داده است.

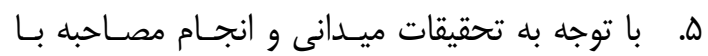

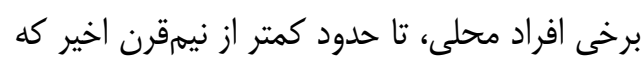

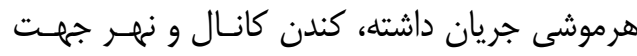
استفاده از آب اين كانال بين ساكنان معاصر مرسوم بوده، بنابراين عمر برخى انشعابات هرموشى حتى ابنى به يك قرن هم نمىرسد.

\section{ه-1. تغيير ات ارتفاعى دشت}

همانطور كه كفته شد بـايين رفـتن بسـتر رودخانسه دز منجر به يايين رفتن سطح آب از دوران باستان تـاكنون

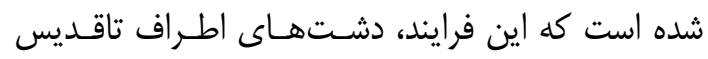

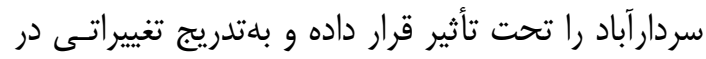

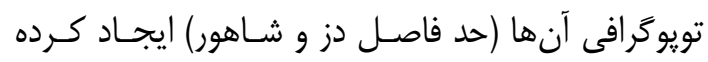

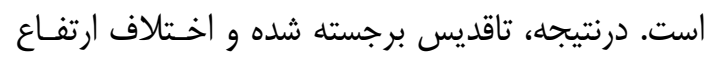
آن با دشتهاى جانبى بيشتر شده است (مقايسه اشـكال

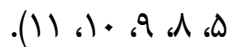

\section{ه-9. بخش همكًراى شاهور و جريانات} سردار آباد

هِ از غيرفعال شــن جريانـات سـردار آباد و كانـالهـا،

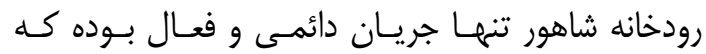

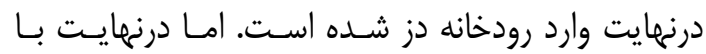

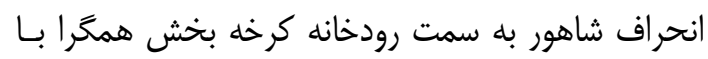

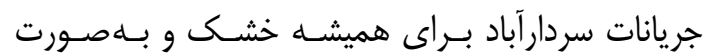
يِيجانرودهاى متروك باقى مانده است كه در شـكل (أ)

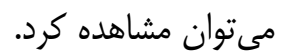

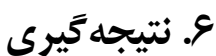

بلهور كلى در اين مطالعه، منابع آبى بــهـــــان معيـارى

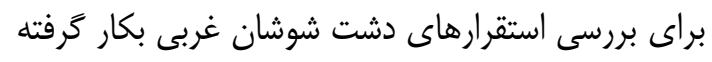

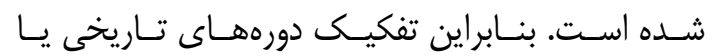
ييشازتاريخى קندان مطرح نيست. هرجند نقش عوامـل

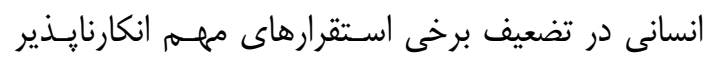

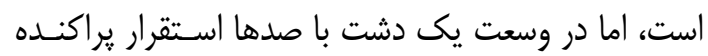
دليل بزركترى لازم دارد. ضمن اينكه شـواهد كـافى از

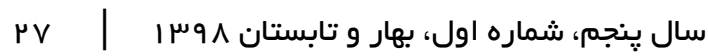

خود اشاره مى كند كه ايلامىها از طريق كانالى به طـول

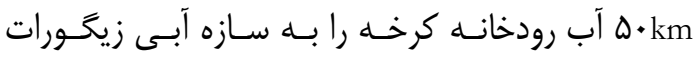

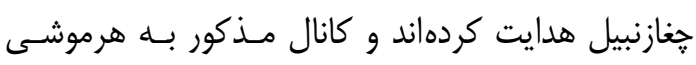
نسبت داده شده[10] كه بهطور كل اين فرضيه نمىتواند

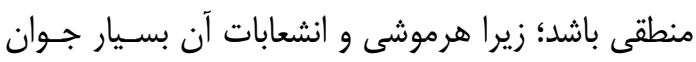

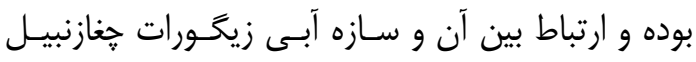

قابليذيرش نيست.

\section{م קرا هرموشى جوان است؟}

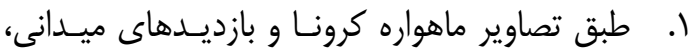
كانال هرموشى و انشعابات آن از روى كانـالهـاى كازي

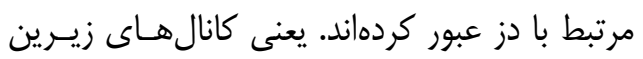

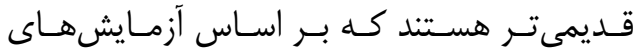

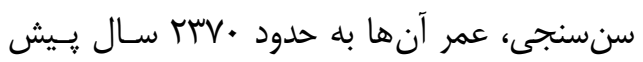
مىرسد و هرموشى بعد از آنها احداث شده است.

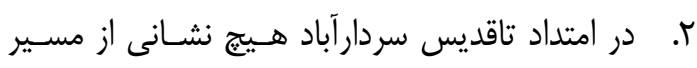

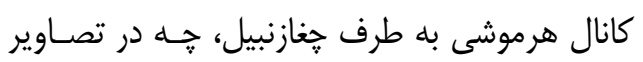

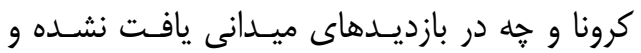
اغلب جريانات طبيعى كه مرتبط با دز بودهانداند عمدتاً از عرض تاقديس عبور كردهاند.

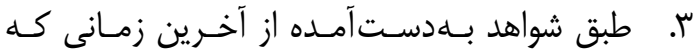

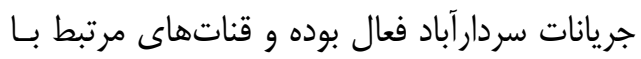

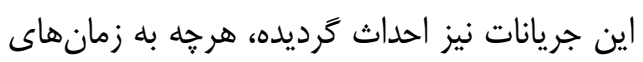
ييشين مانند دوران ايلامى بركرديه، طبيعتـاً سـطح

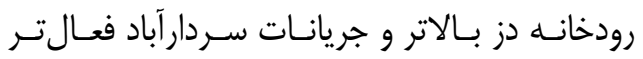

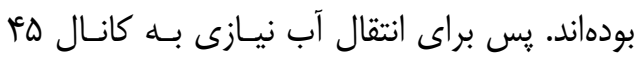

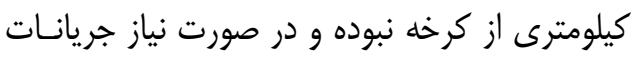

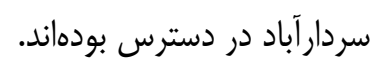
f. هرجند فرسايش در كف رودخانه كرخه و يايين رفتن سطح آب در آن ازلحاظ طبيعى به دليل حوضههـاى ردئ

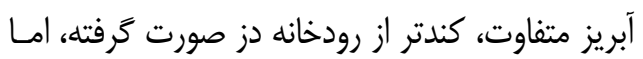
كرخه هـم از ايـن قاعـده مسـتثنى نبــوده و انتظـار مىرفت طس حسدود ..rس سـال (از تـاريخ احـداث

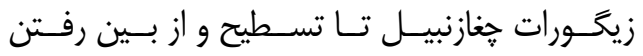

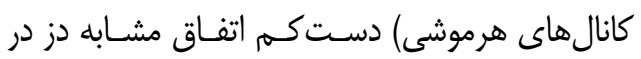
كرخه نيز صورت كيرد؛ درحالى كه هرموشى تا كمتـر از نيمقرن بيش كه تسطيح و تخريب شد، آب كرخه 
استقرارهاى جمعيتى دشت شوشان غربى داشته كه پـس

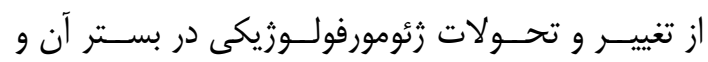

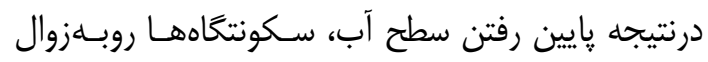

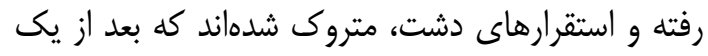
وقفه نامشخص ازنظر زمانى، مجــداً بـا احــــاث كانـال

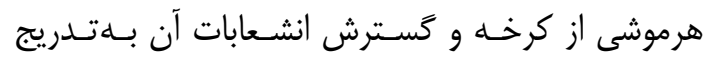

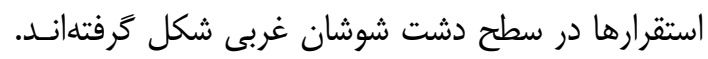

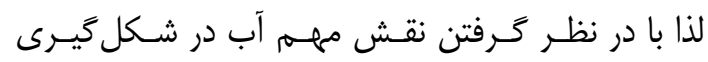

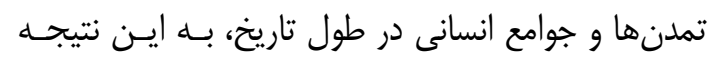

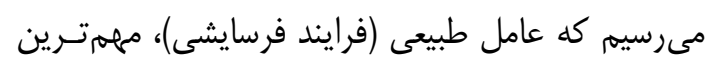

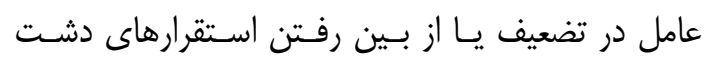
شوشان غربى بوده است.

\section{سباسگَزارى}

با تشكر از همه عزيزانى كه براى ييشـبرد ايـن تحقيـق همكارى كردند.

\section{References}

[1] Maghsoudi M, Sharafi S, Sharfi F. Natural factors affecting the distribution pattern of ancient sites of Silakhor plain in Lorestan province. J Geogr Reg Dev 2016;22:172. [in Persian] [مقصودى، مهران، شـرفى، سـيامك، شـرفى، فاطمـه.

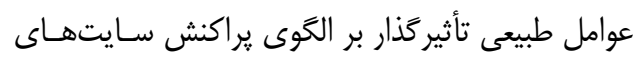

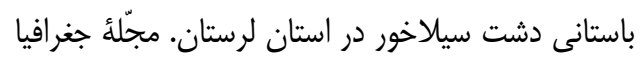

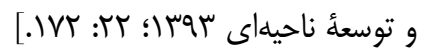

[2] Huckleberry G. Interdisciplinary and specialized geoarchaeology: A post-Cold War perspective. Geoarchaeology 2000;15:523-36.

[3] Brown AG. Geoarchaeology, the four dimensional (4D) fluvial matrix and climatic causality. Geomorphology 2008;101:278-97.

[4] Pedrami M. Absolute Age Quaternary. J Fac Sci 1998;17:71. [in Persian] [يدرامى، منوجهر. سن مطلق كواترنر. مجلـه دانشـكده

علوم Vوسا؛ جلد VIا: (V)

[5] Jean-François B. Hydrological and postdepositional impacts on the distribution of Holocene archaeological sites: The case of the Holocene middle Rhône River
سوى محققين در رابطه با عوامل انسـانى تـاكنون ارائهـ نشده است. در اين بررسى ابتدا تصاوير ماهوارهاى كرونـا

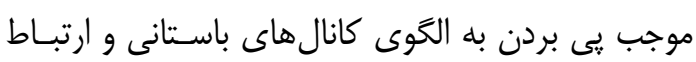
نقش حياتى استقرارهاى دشت شوشان غربى با رودخانسه

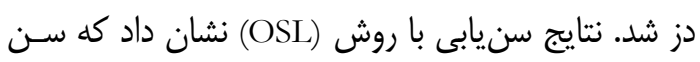

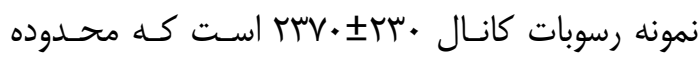

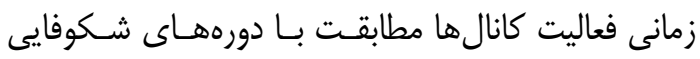

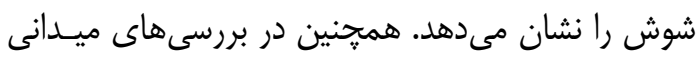
مشخص شد برجستخى بخش شرقى تاقديس سـردارآباد

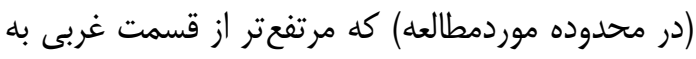
نظر مىرسد حاصل فرسايش دشتهاى جانبى حدفاصل

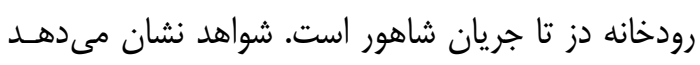

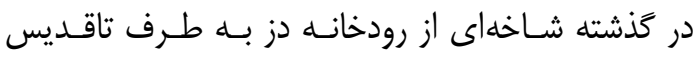

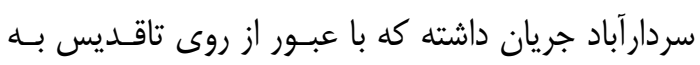

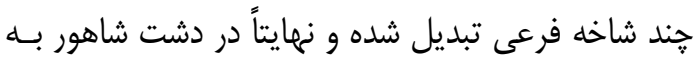

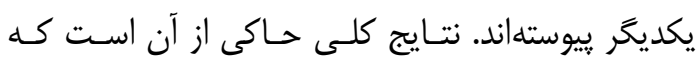

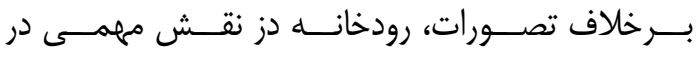

basin, France. Geomorphology 2011;129:167-82.

[6] Hajizadeh A. Reconstruction of the environmental conditions of Holocene human habitats using geomorphologic evidence of Behbahan plain. Tehran, 2019. [in Persian]

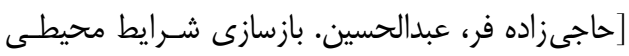

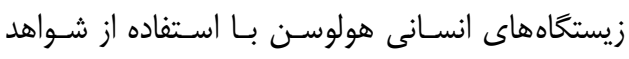

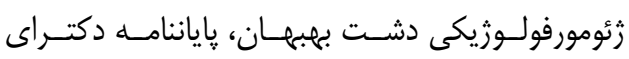

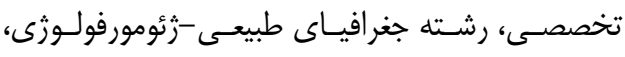

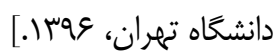

[7] Sardari A. Senjar Hill: A View of a LongTerm settlement in Susiana Plain. In: Azizi Kharanghi N., Khanipour M, Naseri R, editors. Proc. Int. Conf. Young Anc. Sci., Tehran: Faculty of Literature and Science and Cultural Affairs of the University of Tehran; 2016. [in Persian]

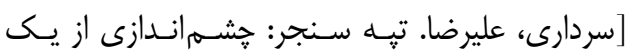

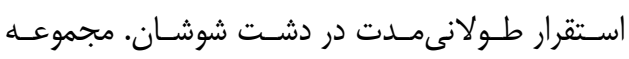

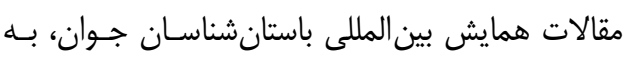
كوشش محمدحسين عزيزى خرانقى، مرتضى خانى بيور 
و رضا ناصرى، تهران: انتشارات دانشكده ادبيات و علوم

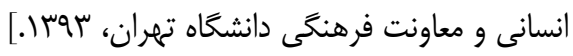

[8] Kirkby MJ. Land and water resources of the Deh Luran and Khuzistan plains. Stud Archaeol Hist Deh Luran Plain Excav Chagha Sefid Univ Michigan, Ann Arbor 1977:251-88.

[9] Kaboli M. Susa and the ancient heritage of Susiana plain. Inst Humanit Cult Stud Cult Heritage, Archaeol Soc Spec 1996:121-32. [in Persian]

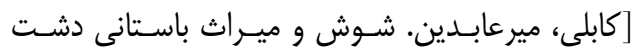

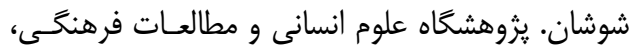

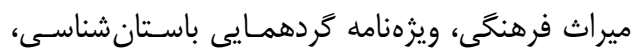

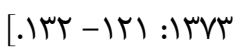

[10] Girshman. Apadana Palace of Susa. J Fac Lit Humanit Univ Tehran 1966;51:14350. [in Persian]

[كيرشمن، ترجمـه سـيد ضـيا الـدين دهشـيرى. كـاخ

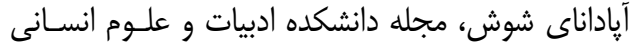

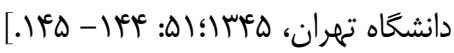

[11] Adams RM. Agriculture and urban life in early southwestern Iran. Science (80- ) 1962;136:109-22.

[12] Alizadeh A, Kouchoukos N, Bauer AM, Wilkinson TJ, Mashkour M. Humanenvironment interactions on the Upper Khuzestan Plains, southwest Iran. Recent investigations. Paléorient 2004:69-88.
[13] Beateman C, Laetitia D, Vanessa H. GeoEnvironmental Investigation. Persian Gulf Shorelines Karkheh, Karun, Jarrahi Rivers A Geo-Archaeological Approach 2005:5-12.

[14] Maghsoudi M, Fazeli Nashili H, Azizi H, Gilmour G, Schmidt A. The role of alluvial fan in the distribution of prehistoric settlements from the perspective of archaeological land (Case study: alluvial fan Jajrood Flying and Haji Arab). Nat Geogr Res 2012:1-22. [in Persian]

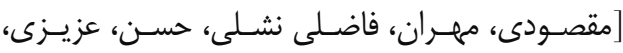

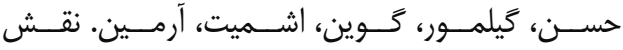

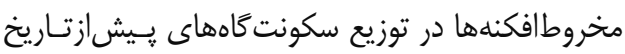

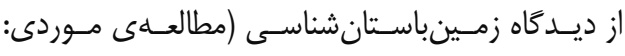

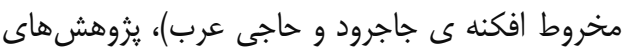

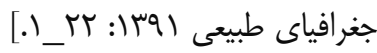

[15] Heyvaert VMA, Baeteman C. A Middle to Late Holocene avulsion history of the Euphrates river: a case study from Tell ed-Dèr, Iraq, Lower Mesopotamia. Quat Sci Rev 2008;27:2401-10.

[16] Rittenour TM. Luminescence dating of fluvial deposits: applications to geomorphic, palaeoseismic and archaeological research. Boreas 2008;37:613-35. 